\title{
Ortaokul 8. Sınıflar Basit Makineler Ünitesine Köy Enstitüleri Örneklerinin Yansımaları
}

\author{
Serkan ALMALI ${ }^{1}$, Ahmet AKBAŞ2
}

${ }^{1}$ Fen Bilimleri ögretmeni,Milli Ë̆itim, marmarafen@,hotmail.com² Prof.Dr.Mersin Üniversitesi, abmetakbas@mersin.edu.tr

DOI: http://dx.doi.org/ 10.14582/DUZGEF.1905

ÖZ

Araștırmanın amac1; bir dönem köy enstitülerinde yapılan etkinliklerin ortaokul 8.sınıflar basit makineler ünitesine yansımalarını belirlemek, bu yansımaların öğrencilerin akademik başarılarına ve fene karşı tutumlarına etkisinin olup olmadığıı araştırmaktır. Çalısmada yarr-deneysel desenlerden eșitlenmemiș kontrol gruplu desen kullanılmıștır. Araștırma Mersin ili Akdeniz ilçesindeki bir ortaokula devam etmekte olan 8. sınıf öğrencileri ile yürütülmüștür. Araștırmanın verileri 2016-2017 öğretim yllı birinci döneminde, on haftalık bir sürede toplanmıştır. Veri toplama aracı olarak, "Akademik Başarı Testi”" ve "Fen ve Teknoloji Dersine Yönelik Tutum Ölçeğì" öğretime başlamadan önce uygulanmışıtır. Köy enstitüleri örneklerinin yansımaları ile öğretim yapılan deney grubu öğrencileri ile programın öngördüğü öğretim yönteminin uygulandığ kontrol grubu öğrencileriyle "Basit Makineler" ünitesi işlenmiştir. Konunun bitimindeheriki gruba daölçekler bu kez son testolarak uygulanmıştır.

Araştırmanın tanımlayıcı verileri sayı, ortalama, standart sapma, frekans ve yüzde ile değerlendirilmiştir. Toplanan verilerin analizinde, tek faktörlü varyans analizi ve Pearson korelasyon kullanılmışıtr.

Araştırmanın bulguları, uygulanan tüm testlerde son test ön test puan farkları arasında deney grubu lehine anlamlı bir farkın olduğunu göstermiş̧ir. Başarı ve tutum son test puanları arasında istatiksel bakımdan anlamlı pozitif yönde yüksek düzeyde bir ilişki olduğu görülmüsstür. Elde edilen sonuçlar șsığında köy enstitülerindeki etkinlik örnekleriyle ve "iş"i temel alarak yapılan öğretimin öğrencilerin başarılarını ve fene karşs tutumlarını olumlu şekilde değiştirmiş olduğu söylenebilir.

Anahtar Kelimeler: fen bilimleri, akademik başarı, fen bilimlerine yönelik tutum, köy enstitüleri

\section{The Reflections of the Village Institutes' Examples on Secondary School 8th Grade Simple Machines Unit}

\begin{abstract}
The purpose of this study is to identify the reflections of the activities on secondary school 8th grade simple machines unit in the Village institutes and find out whether these reflections have effects on the students' academic achievements and attitudes towards Science. Nonequivalent groups design, one of the quasi-experimental design, was used in the study. The study was carried out with $8^{\text {th }}$ grade students attending a secondary school in Akdeniz district in Mersin. The data of the study were collected during 10-week period in the first semester in 2016-2017 academic year. "Academic achievement test" and "Attitude towards Science and Technology Class Scale" were administered before the instruction as data collection tools. "Basic Machines" unit was studied with the students in the experimental group, who were taught with reflections of the activities on secondary school 8th grade simple machines unit in the Village institutes and with the students in control group, where the teaching method set forth by the program was used. After the experiment, the data collection tools were administered as posttests.

For the descriptive data, numbers, mean, standard deviation, frequency and percentage were used. One-way ANOVA and Pearson correlation were administered for the collected data.

The findings revealed that there is a significant difference between the pre-test and post-test score variation in all the tests administered on behalf of the experimental group. A statistically significant positive relationship was found between the achievement and attitude posttest scores. In the light of the results obtained, it can be stated that the teaching based on "action" and done with the activity samples in the Village institutes have changed the students' academic achievements and attitudes towards science and technology class positively.
\end{abstract}




\section{GİRİŞ}

Eğitim insan yaşamının kalitesini doğrudan etkileyen bir süreçtir. Kimi zaman, alınacak iyi bir eğitim kaliteli bir hayatın da habercisi olabilmektedir.

Günümüz dünyasında da eğitim, insan yaşamının nitelikli olması açısından önemli bir hal almıştır. $\mathrm{Bu}$ sebeple tüm bireylerin anlamlı yaşamaları için belirli bir eğitim sürecinden geçmeleri gerekir (Çelik, 2015). Eğitim sistemimizdeki uygulamalarda artık öğrencinin merkeze yerleştĭ̆i, kendi öğrenme tarzlarına uygun olan yeni yaklaşımlar yer almaktadır. Bu yeni yaklaşımlar dolayısıyla eğitimde kullanılan araç-gereçlerde yenilenmeye gidilmiştir. Bu gelişmelerden en çok etkilenen ve değişime uğrayan disiplin alanı da fen bilimleri olmuştur (Karasel ve Özçınar, 2008).

Süratle gelişen dünyamızda eğitim anlamında bilim ve fenin önemi çok büyük bir yer tutmaktadır. Fen eğitiminin etkili olması, öğrencileri ezbere yönlendirmek yerine, öğretilecek kavramların anlamlı öğrenilmesi ve içselleştirilmesi sağlanarak gerçekleşebilir. Şimdiye kadar yapılan çalışmalar anlamlı öğrenmenin önemini ortaya koymuştur. Yine yapılan çalısmalar standart testlerde başarısı yüksek öğrencilerin öğrendikleri bilgileri gerçek hayatta uygulamada zorlandıklarını göstermektedir (Arslan, 2007). Bu ve benzeri sebeplerden dolayı, gelişmiş ülkeler önde olmak üzere tüm toplumlar devamlı olarak Fen Bilimleri eğitimini yaygınlaştırmak ve kalitesini artırma çabası içerisindedirler (Maskan ve Maskan, 2007).

Bireyler, hızla değişen dünyaya uyum sağlayabilmek için yaşam boyu öğrenmeyi benimsemelidirler (Can, 2003). Bireylerin öğrendiklerini günlük hayata aktarabilmeleri, yaratıcı düşünmeleri günümüz eğitim anlayışının temel taşlarından biridir (Şen, 2009). Öğrencilere kazandıkları fen becerilerinin tek bir alanda değil de günlük yaşantılanının her alanında faydalı olacağı vurgulanmalıdır. Kılınç’a (2013) göre öğrencilere, günlük hayattaki problemleri, bilimsel süreç basamaklarını kullanarak çözebilecekleri, bilimsel düşünebilecekleri, yaparak yaşayarak öğrenebilecekleri, kendi bilgilerini oluşturabilecekleri, ilgilerini çekecek, sevebilecekleri ortamlar sağlanmalıdır. Öğrencilerin bu özellikleri kazanabilmesi ve yaşam boyu kullanabilmeleri için hem okullarda hem de okul dışındaki ortamlarda desteklenmeleri gerekmektedir (Böyük, Saraçoğlu ve Tanık, 2011).

Öğrencilere yaparak-yaşayarak öğrenebilecekleri ortamların hazırlanması, öğrencilerin bilimsel yöntem süreç becerilerini kazanmalarına ve serbestçe düşünebilmelerine de yol açacaktır (Kaptan, 1999). Öğrencileri yaparak-yaşayarak, uygulamalar yaptırarak derse dahil etmek, böyle ortamları onlara sağlamak Fen eğitiminde, yapılandırmacı yaklaşımın ve sorgulamaya dayalı öğretimin istendik davranışlarındandır. Örneğin öğrencilere verilecek bir iş, bilim temelli bir etkinlik dersi hem anlamlı hem de eğlenceli hale getirebilir. Öğrenci öğrenme sürecinde ne kadar aktif olursa hedeflenen kazanımlara ulaşmak ta o kadar kolay olur (Çelik, 2015). Bu yüzden, öğretmenler ögrencilerin hedeflenen kazanımlara ulaşması için, anlatacakları konuların yapısına göre farklı öğretim yöntem ve tekniklerini kullanmalıdırlar.

Bu yöntemlerden biri de bir dönem Köy Enstitülerinde de kullanılan iş eğitimidir. Köy enstitülerinde iş içinde iş, iş içinde öğrenme vardı. Öğrenciler bir işi uygulamalı olarak yaparken öğreniyorlardı. Doğanın içinde, işin içinde olduğu eğitimde de fen bilimleri başarılı bir biçimde öğreniliyordu. Örneğin çiçeğin yapıs1 anlatılacağı zaman sınıf ortamında bir modelleme ile değil de doğanın içinde öğrencinin keşfetmesine olanak sağlanıyordu. En donanımlı okullarda bile fizik dersinde kaldıracı, matematik dersinde Pisagor Kuramını, biyolojide tozlaşmayı, az sayıda laboratuvar çalışması ve sınırlı araç gereçle birer deneme ve anlatma yöntemiyle öğretmeye çalışırken, enstitü öğrencileri bunları yaşamın gerçek işleri ve çalışmaları içinde daha kolay ve kalıcı öğreniyorlardı. Üstelik o bilginin kullanıldığı yeri, ya da o bilgilerden yararlanılarak neler yapıldığını, dersler ve konular arasındaki bağlantıları da somut olarak görüyorlardı. El arabası ya da başka bir gereci kullanırken kaldıracı, bir yapının çatısını kurarken Pisagor kuramını, işlerle kuralları birleştirerek iş içinde ve kalıcı olarak, bilginin işlevini görerek, bilinçle öğreniyorlardı. Yani bu yöntemle ezbere dayalı değil kalıcı ve anlamlı öğrenme esas tutuluyordu (Türkoğlu, 2000).

Köy enstitülerinde günümüzde fen bilimleri kapsamında olan "tabiat bilgisi, okul sağllk bilgisi, fizik ve kimya" derslerinin öğretimi günlük yaşamın ihtiyaçları göz önünde bulundurularak yapilıyordu. Enstitü yaşamının tamamında, bu derslerin konularını içerecek işler, bu işlerde kullanılacak araç gereçler ve bu işler 
sonucunda öğrencilerin elde ettiği ürünler vardı (Türkoğlu, 2000). Enstitülerde fen bilimlerinin amac1, öğrencilere bilimsel yöntemi kazandırmak, karşılaşılan araç ve maddelerin özelliklerini ve onlardan yararlanma yollarını öğretmek olarak oluşturulmuştu. Doğayla iç içe olan bir ortamda, yapılan işler sürecinde öğrencilerin bilimsel arayış yollarını bulmaları, karşılaştıkları madde ve araçların özelliklerini de öğrenmeleri kendiliğinden gerçekleşiyordu (Gökçe, 2010).

Belirtilen sebeplerden ötürü köy enstitülerindeki gibi iş eğitimi esas alınarak, öğrencilere bir iş yaptırmaya yönelik hazırlanacak dersler ya da enstitülerdeki gibi sınıf ortamında değil de doğal ortamlarda uygulamalı yapılacak etkinlikler öğrencilerin akademik başarılarında ve fene karşı tutumlarında etkili olacak, öğrencilerin özellikle karmaşık bulduğu basit makineler gibi bir üniteye daha olumlu bakmalarını ve günlük hayatla ilişkilendirmelerini sağlayacaktır.

\subsection{Araştırmanın Problemi}

Ortaokul Fen Bilimleri dersinin 8. Sınıf "Basit Makineler” ünitesinin öğretiminde; Köy Enstitüsü örneklerinin yansımalarıyla yapılan öğretimin, Öğrencilerin Başarısına ve Fen Bilimlerine Yönelik Tutumuna Etkisi Nedir? Öğrencilere uygulanan başarı testi ve tutum ölçeği sonuçları arasında bir ilişki var mıdır?

\section{Alt Problemler}

1. Köy Enstitüsü örneklerinin yansımalarıyla fen öğretiminin yapıldığı deney grubu öğrencileri ile mevcut öğretim programının önerdiği yöntemin uygulandığı kontrol grubu öğrencilerinin, başarı puanları arasında anlamlı bir fark var midır?

2. Deney grubu öğrencileri ile kontrol grubu öğrencilerinin, fen bilimlerine yönelik tutum puanları arasında anlamlı bir fark var midır?

3. Deney grubu öğrencileri ile kontrol grubu öğrencilerine son test olarak uygulanan başarı ve tutum puanları arasında anlamlı bir ilişki var mıdır?

\subsection{Araştırmanın Amacı}

Fen kavramının öğrenciler tarafindan anlaşılabilmesi, soyut kalmaması için günlük yaşamdan örneklerle pekiştirilmesi gereklidir. Aksi takdirde anlama olmayacaktır (Gürdal, 2001). Yaparak-yaşayarak öğrenmeyi temel alan bir fen eğitimi ile kavramlar soyut kalmayacak daha anlaşıllır bir hale gelecektir. Köy Enstitülerinin 1943 ve 1947 programlarına bakıldığında öğretimde "Bizzat yapma" ve "yaşama”ya çok büyük önem verildiği görülmektedir. Düz anlatım, soru-cevap gibi klasik yöntemlerden bahsedilmemekte hatta çoğu zaman da eleştirilmektedir. Yapılan etkinlikler, öğretmenin robot gibi dümdüz anlatması ile değil, öğrencilerin düşünmesine, işe dönüştürmesine yönelikti (Kaplan, 2002). Yapılan etkinlikler "iş içinde iş aracıllğıyla eğitim” biçiminde yapılırdı (Binbaşıŏglu, 1993). Yaparak yaşayarak öğrenme ilkesiyle köy enstitüleri başarıya ulaşmıştır (Kaplan ve ark., 1993).

$\mathrm{Bu}$ araştırmanın temel amacı bir dönem köy enstitülerinde yapılan etkinliklerin Ortaokul 8.sınıflar basit makineler ünitesine yansımalarını görmektir. Bu yansımaların öğrencilerin başarılarına ve fen bilimlerine yönelik tutumlarına etkisinin olup olmadığını araştırmak, başarı ve tutum arasında bir ilişki olup olmadığını belirlemektir.

\subsection{Araştırmanın Önemi}

Yaparak-yaşayarak yapılan fen etkinlikleri ile öğrencilerin tüm duyu organlarını kullandıkları ve bu sayede somut gelişim düzeyinden, daha soyut düşünme düzeyine geçtikleri görülmüş̧ür (Jones ve ark., 2003). "Yaparak-yaşayarak öğrenme etkinlikleri öğrenci merkezli öğretim yaklaşımları ile yapıldığında öğrencilerin bilimsel süreç becerileri daha iyi gelişir" şeklindeki verileri de desteklemektedir (Hofstein ve Lunetta, 2004). Fakat bu etkinliklerin öğretmen tarafından gösteri şeklinde yapılması durumunda öğrenciler aktif değillerdir ve bu durum öğrencilerin anlamlı öğrenmelerinde çok da etkili değildir.

Tonguç’un önderliğinde kurulan köy enstitülerinde iş yöntemine göre öğrencilere öğretilmek istenen bir konuyla ilgili iş verilirdi. Bu işler, harita yapımı, piyes oynama, metin hazırlama hatta bina yapımına kadar giderdi. Bu işlerin yapılması sayesinde de öğrencilere kazandırılmak istenen bilgi, beceri, tutum ve alışkanlıklar kazandırılırdı. Mesela, uzunluk, alan, hacim ölçüleri havuz yapılması işi içinde öğretilebilirdi (Binbaşığlu, 
1993). Demirtaş’a (1993) göre enstitülerde uygulanan programların, yaparak ve yaşayarak öğrenmeye yer vermesi, "İş" ve “etkinlik" ilkelerine göre hazırlanması başarıya ulaşmadaki isabetli yönleridir.

Türkoğlu (2000), “Tonguç ve Enstitüleri” adlı kitabında Fakir Baykurt'un Gönen Köy Enstitüsünde iken kuramla gerçek işi somut olarak iş içinde öğrendiğini belirten anlatımına şu örneği veriyor: Gönen Köy Enstitüsünde Fakir Baykurt'un da aralarında bulunduğu öğrencilerle, Tina Dağı'ndan 9 km uzunluğunda, 80 cm derinliğinde kanal kazılıp enstitüye su getirilmesi planlanıyor. Baykurt içinden bu işin saçma olduğunu, suyu getirmenin mümkün olmadığını düşünüyor. Bu arada öğretmenler de bir yandan iş yapılırken fizikteki bileşik kaplar yasasını anlatıyorlar. Sonunda ihtiyaç olan malzemelerin alınmasından harç işlemine kadar her şey bitirilip güzel bir depo yapıyorlar. Kazı esnasında sağlık simgesi olduğunu öğrendikleri Roma devrinden kalma bir taş bulup onu da deponun altına yerleştiriyorlar. Bütün bunların ardından Baykurt bir de şiir yazıp törende okuyor ve yaptıkları işlerin, öğrendikleri konuların hangi derslerle ilişkili olduğunu anlatıyor. Yani verilen bir görev ya da yapılan bir iş esnasında birden fazla dersle ilişki kuruluyor, ya da iş içinde bilim yasaları ve kuramlardan bahsedildiği görülüyordu.

Fen bilimleri dersinde "Basit makineler" ünitesi diğer ünitelere göre daha karmaşık bir yapıdadır. Bu ünite öğretilirken öğretmenin sunum yapmas1, örneklerle formülleri vermesi öğrencilerin konuyu özümseyememelerine sebep olmaktadır. Bu sebepten olacak ki birçok araştırmacı bu ünitenin öğretilmesi kapsamında farklı öğretim yöntem ve teknikleri kullanmışlardır (Ayvazoğlu 2016, Burkaz 2012, Çelik 2015, Irkıçatal 2016, Telli 2002, Timur 2006 ve Yilmaz 2005). Bu çalışmada da kullanılacak öğretim yöntemi ile öğrenciler bir iş yaparken konuyu öğrenecekler ve gerçek hayatla bir ilişki kurabileceklerdir. "Basit makineler" ünitesindeki birçok makinenin günlük hayatı kolaylaştırdığını, İstanbul’un fethinde kullanılan gemileri kaydıran kızaklara kadar hepsinin birer basit makine olduğunu ve insanlığın en eski tarihlerinden beri bu makine örneklerinin yaşamın içinde olduğunun farkına varacaklardır. Bu sayede de öğrenciler tarafından karmaşık bulunan bu konu daha iyi kavranabilecektir. Bu yüzden ünite işlenirken teorik bilgilerin yanında öğrencilerin pratik uygulama yapacağı öğrenme ortamlarının hazırlanmasına dikkat edilmiştir. Etkinliklerin "iş"e dayalı okul dışında bahçede yapılacak olması da bu ünitenin uygulanabilirliği açısından, seçilmesinde etkili olmuştur.

Okul dışı ögrenme ortamlarından yararlanılması gerektiği fen programında şu şekilde ifade edilmiştir: Okul dışı ve sınıf içi öğrenme ortamları, araştırma-sorgulamaya dayalı öğrenme stratejisine göre hazırlanır. Bu durum öğrencilerin fen alanındaki bilgileri daha anlamlı ve kalıcı öğrenmelerini sağlar. Bu anlamda informal öğrenme ortamlarından da faydalanılır (MEB, 2018). İnformal yani okul dışında öğrenmenin temel özellikleri arasında; sınıfin dışında, müzeler, hayvanat bahçesi, doğal ortamlar, botanik bahçeleri, okul bahçeleri vb. ortamlarda gerçekleşmesi, öğrencilerin süreç boyunca aktif olmaları, ilgi ve isteklerinin üst düzeyde olmaları, sürece heyecanla katılım gerçekleştirmeleri ve birden çok duyu organına hitap ederek öğrenmenin kalıcı olmasını sağlaması sayılabilir. Bu tür öğrenme, öğrencilerin bizzat yaşayarak, soyut bilgileri somutlaştırarak, eğlenerek bilgi edinip, edindikleri bilgileri yaşamlanı boyunca kullanabilecekleri bir yaklaşım sunmaktadır (Armağan, 2015).

Bu kapsamda yapılan bu çalışmada işlenen dersler köy enstitülerindeki örneklerine benzer şekilde, sınıf ortamında sınırlı kalmayıp, okul dışında, doğayla iç içe, ve genelde bir iş yapmaya yönelik etkinlikler kapsamında gerçekleştirilmiştir. Bu etkinliklerin yapıldığı deney grubunda başarının artacağı, fene karş1 tutumlarının gelişeceği düşünülmektedir. Bu çalışmadan hareketle Basit Makineler ünitesine benzer diğer fen konularının da bu tür etkinliklerle yapılabileceği düşünülmektedir.

Köy enstitüleri ve fen eğitimi konusunda ülkemizde çok fazla araştırmanın gerçekleştirilmediği düşünüldüğünde bu araştırmanın alan yazına katkı sağlayacağı umulmaktadır.

Bulunduğu dönem içerisinde yaparak-yaşayarak öğrenmenin aktif bir şekilde yapıldığı, yaptığı çalışmalarla başanya ulaşmış, günümüzde ise işlevini yitirmiş olan Köy enstitülerini de bu çalışmayla kısaca hatırlayacak olmamız, değişik bakış açıları kazandırması bakımından bu tez çalışmasını önemli kılmaktadır. 


\section{YÖNTEM}

\subsection{Araştırma Modeli}

$\mathrm{Bu}$ çalışmada araştırma modeli olarak, yarı-deneysel desenlerden eşitlenmemiş kontrol gruplu desen kullanılmıştır. Yarı deneysel model, gerçek deneme modellerinin gerektirdiği kontrollerin sağlanamadığı durumlarda kullanılır. Bu modelde gruplardaki öğrencilerin yansız bir şekilde seçimi yapılmaz. Oluşturulan gruplar belli gerekçelerle bir araya getirilmiş öğrencilerden meydana gelir (Karasar, 2013). Yarı deneysel yöntem eşitlenmemiş gruplara sadece son test uygulaması, tek bir gruba ön ve son test uygulaması ve eşitlenmemiş gruplara ön ve son test uygulaması gibi değişik şekillerde uygulanabilir (Çepni, 2007).

Bağımlı değişken, yapılan çalışmanın bir tür sonucu olup, açıklanması istenen durumdur Karasar (2013). Bu çalışmanın bağımlı değişkeni öğrencilerin akademik başarıları ve fen bilimlerine yönelik tutumları olarak belirlenmiştir. Bağımsız değişken ise araştırmacının yaptı̆̆ı değişimler sonucu etkilenen değisskendir (Karasar, 2013). Bu çalışmanın bağımsız değişkeni ise öğretim yöntemidir.

Çalışmada iş ve eğlenceye dayalı etkinliklerin faydalı olup olmadığını anlamak için ortaokul 8.sınıfa giden öğrencilerden kişisel bilgi formları dikkate alınarak 2 grup oluşturulmuştur. Bu gruplardan tarafsız ve rastgele bir şekilde biri deney, diğeri de kontrol grubu olarak belirlenmiştir. Kontrol grubu öğrencilerine MEB programının önerdiği yöntem ile; Deney grubu öğrencilerine ise iş ve eğlenceye dayalı etkinliklerle ders işlenmiştir. Çalışma fen dersinin yanında bilim uygulamaları dersiyle birlikte kontrol ve deney grubu için ayrı ayrı hazırlanan ders planlarıyla 8 hafta süreyle devam etmiş, ön ve son testler içinde birer hafta kullanılmıs ve toplam 10 hafta ile sonuçlandırılmışır. Çalışmada deneysel işlemler başlamadan önce ve deneysel işlemlerin bitiminde, deney ve kontrol gruplarına başarı testi ve tutum ölçeği uygulanmıştır.

\section{2. Çalışma Grubu}

Bu çalışma 2016-2017 eğitim-öğretim yllında Mersin ili Akdeniz ilçesinde bulunan bir ortaokulda eğitim görmekte olan tüm 8.sınıf ögrencileri ile yapılmıştır. Araştırmanın deney ve kontrol grubunu belirlemek için öğrencilere deneysel işlemden önce "Kişisel Bilgi Formu” uygulanmıştır. Öğrencilerin cinsiyetleri ve 7. sınıf Fen Bilimleri dersi not ortalamaları dikkate alınarak eşit dağılımlı sınıflar arasından iki grup oluşturulmuştur. Sınıfların ortam koşulları ve dersin işlenme süresi gibi değişkenlerin de aynı olmasına dikkat edilerek seçkisiz şekilde gruplardan biri deney diğeri de kontrol grubu olarak belirlenmiştir. Bunun sonucu olarak 8/A olarak belirlenen sınıf kontrol grubunu, 8/B sınıfi ise deney grubunu oluşturmuştur. Deney grubu öğrencilerine (8/B sınıfi) ünite boyunca ( 8 hafta) iş ve etkinliklere dayalı öğretim, kontrol grubu öğrencilerine (8/A sınıfi) ise MEB programının önerdiği yöntem ile fen bilimleri ders kitabındaki etkinlikler uygulanmıştır. Deney ve kontrol grubunda yer alan öğrencilerin cinsiyetleri ile analizleri tablo 1'de sunulmuştur.

Tablo 1. Gruplarda yer alan kız ve erkek öğrenci dağılımı

\begin{tabular}{|c|c|c|c|c|c|c|}
\hline \multirow{3}{*}{ GRUPLAR } & \multicolumn{4}{|c|}{ CINSIYYET } & \multirow{2}{*}{\multicolumn{2}{|c|}{ TOPLAM }} \\
\hline & $\mathrm{KIZ}$ & & $\overline{\mathrm{KEK}}$ & & & \\
\hline & $\mathrm{f}$ & $\%$ & $\mathrm{f}$ & $\%$ & $\mathrm{f}$ & $\%$ \\
\hline $\begin{array}{l}\text { Deney } \\
\text { Grubu }\end{array}$ & 12 & 27.3 & 11 & 25 & 23 & 52.3 \\
\hline $\begin{array}{l}\text { Kontrol } \\
\text { Grubu }\end{array}$ & 11 & 25 & 10 & 22.7 & 21 & 47.7 \\
\hline TOPLAM & 23 & 52.3 & 21 & 47.7 & 44 & 100 \\
\hline
\end{tabular}

\subsection{Veri Toplama Araçları}

\subsubsection{Başarı Testi}

"Basit makineler" ünitesiyle ilgili Başarı Testi, araştırmada deney ve kontrol grubunda yer alan öğrencilere, uygulanan öğretim yöntemleri sonucunda gösterdikleri başarıyı ölçmek amaciyla ön ve son test olarak uygulanmıştır. Bu amaçla 2016-2017 Eğitim-Öğretim yılı için Milli Eğitim Bakanlı̆̆1 Ölçme, Değerlendirme ve Sınav Hizmetleri Genel Müdürlüğü tarafindan hazırlanan kazanım kavrama testleri kullanılmıştır. "Basit makineler" ünitesinde toplam 3 kazanım bulunmaktadır. Bunlar: 
Basit makinelere örnekler verir ve sağladığı avantajları örneklerle açıklar.

Basit makinelerden, sabit makara, hareketli makara, palanga, kaldıraç, eğik düzlem ve çıkrık üzerinde durulur.

Dişli çarklar, vida ve kasnakların da birer basit makine olduğu belirtilir.

Basit makinelerde işten kazanç olmadığı vurgulanır.

> Basit makinelerin günlük yaşamdaki kullanım alanlarına örnekler verir.

$>$ Basit makinelerden yararlanarak günlük yaşamda iş kolaylı̆̆ı sağlayacak bir düzenek tasarlar ve yapar.

Bu kazanımlar doğrultusunda MEB Ölçme, Değerlendirme ve Sinav Hizmetleri Genel Müdürlüğünün tamamı çoktan seçmeli toplamda 39 sorudan oluşan 4 kazanım kavrama testinin, aynı hedef davranışı ölçen soru sayısının fazla olmasından, öğrencilerin çok fazla soruyu cevaplamaktan dolayı sıkılacaklarının düşünülmesinden ve yaş seviyelerinin de düşük olmasından dolayı azaltılmasına karar verilmiş. Testin geçerliliği de göz önünde bulundurulmak suretiyle bir profesör ve iki fen bilimleri öğretmeni olmak üzere üç uzman görüşü alınarak tek bir teste ve 20 soruya düşürülmüştür.

Başarı testi bir ders saati sürecince uygulanmıştır. Testteki her bir sorunun doğru cevabının puanı “5” olarak tespit edilmiş ve "100” tam puan üzerinden toplam puanlar hesaplanmıştır.

\subsubsection{Fen Bilimlerine Yönelik Tutum Ölçeği}

Araştırmada öğrencilerin Fen Bilimleri dersine yönelik tutumlarını belirlemek için Çakır, Şahin ve Yanpar (2000), tarafindan geliştirilmiş 14'ü olumlu 13'ü olumsuz olmak üzere toplam 27 maddeden oluşan tutum ölçeği kullanılmıştır. Tutum maddelerinde olumlu cümlelerde;

Tamamen Katiliyorum $=5$

Kat1liyorum $=4$

Kararsizım=3

Katılmiyorum $=2$

Hiç Katılmıyorum=1 Puan iken, olumsuz cümlelerde ise;

Tamamen Kat1liyorum $=1$

Kat1liyorum $=2$

Kararsızım $=3$

Katılmiyorum $=4$

Hiç Katılmıyorum=5 puan olarak hesaplanmıştır.

Ölçeğin Croanbach Alpha güvenirliği geliştirenler tarafindan ,95 olarak bulunmuştur. Bu araştırmada ölçeğin Croanbach Alpha güvenirliği ,86 bulunmuştur. Fen Bilimlerine Yönelik Tutum Ölçeği uygulama öncesinde ve sonrasında deney ve kontrol grubundaki öğrencilere uygulanmıştır. Uygulama sonuçları karşılaştırılarak grupların fen dersine yönelik tutumları arasında anlamlı bir değişimin söz konusu olup olmadı̆̆1 belirlenmeye çalışılmıştır.

\subsection{Verilerin Toplanmas1}

Deney grubundaki öğrencilere, köy enstitü örneklerinin yansımalarından yola çıkılarak, sınıf dışında hazırlanan etkinlik planları ile "Basit makineler" ünitesi 8 haftalık süre içerisinde işlenir. Basit makineler ünitesine haftalık ders programında 5 haftalık süre tanınmıştır. Fakat araştırmacı öğrencilerin tutumlarında bir değişiklik olup olmadığını görmek için Bilim Uygulamaları dersinde de üniteye devam etmiş, ön ve son test içinde birer hafta kullanarak toplam süreyi 10 haftaya çıkarmıştır. Kontrol grubundaki öğrencilerle ise programin öngördüğü yöntemle dersler işlenmiştir. Deneysel işlemler tamamlandıktan sonra deney ve kontrol gruplarına bu sefer son test olarak yine aynı ölçekler uygulanmıştır.

Kontrol grubuna fen bilimleri ders kitabındaki etkinlikler yaptırılmıştır. Deney grubunda ise hazırlanan etkinlikler uygulayıcı tarafından hazırlanmış, bir iş yaptırmaya yönelik olarak düzenlenmiş ve öğrencilerin etkinlikleri yaparken o işi yaşamaları ve konuyla ilgili kazanımları öğrenmeleri amaçlanmıştır. Köy enstitülerinde de çoğunlukla uygulanan bu yöntem “iş içinde iş aracıllğıyla eğitim” biçiminde yapıllırdı. Örneğin öğrencilere öğretilmek istenen bir konuyla ilgili iş verilirdi. Bu işler, harita yapımı, piyes oynama, metin 
hazırlama hatta bina yapımına kadar giderdi. Bu işlerin yapılması sayesinde de öğrencilere kazandırılmak istenen bilgi, beceri, tutum ve alışkanlıklar kazandırılırdı. Mesela, uzunluk, alan, hacim ölçüleri havuz yapılması işi içinde öğretilebilirdi (Binbaşığlu, 1993).

Deney Grubunda Uygulanan Etkinlikler

$>$ Çalışiyorum

> Bahçemi Güzelleştiriyor, Araç Tekeri Değişiyorum

$>$ Çok Kuvvetliyim

$>$ Kuvvetten Kazaniyorum

$>$ Direksiyon Öğreniyorum

$>$ Bisiklete Biniyorum

$>$ İşten Kazanç Yok

> Kendi Makinemi Tasarliyorum

"Çalışıyorum” etkinliğinde öğrencilerden bahçede bulunan çöp kovasının yerini değiştirerek iş yapmaları ve tahterevalli örnekleri yapmaları istenerek basit makinelerden tek ve çift taraflı kaldıraçlar üzerinde durulur.(Ek 6, Etkinlik 1)

"Bahçemi Güzelleştiriyor, Araç Tekeri Değişiyorum” etkinliğinde öğrencilerden bahçe makaslarıyla bahçedeki zeytin ağaçlarını budamaları ve böğürtlen dikenlerini temizlemeleri, kriko yardımıyla da araba tekerini değiştirmeleri istenerek basit makinelerden tek ve çift taraflı kaldıraçlar üzerinde durulur.(Ek 6, Etkinlik 2)

“Çok Kuvvetliyim” etkinliği ile öğrencilerden bayrağı göndere çekmeleri, salıncak direğine kurulan caraskal yardımı ile ağır yükleri yukarıya çıkarmaları istenerek basit makinelerden sabit makara, hareketli makara ve palanga üzerinde durulur. (Ek 6, Etkinlik 3)

“Kuvvetten Kazanıyorum” etkinliği ile öğrencilerden okul için gerekli briketleri taşımaları ve okul çatısına yapılan öğretmenler odası için kullanılacak tahtalanı birbirlerine tutturmaları istenerek basit makinelerden eğik düzlem üzerinde durulur. (Ek 6, Etkinlik 4)

“Direksiyon Öğreniyorum” etkinliği ile öğrencilerden araç kapısını açmaları ve çalışır vaziyetteki aracın direksiyon koltuğuna oturarak direksiyonu sağa sola çevirmeleri istenerek basit makinelerden çırrk üzerinde durulur. (Ek 6, Etkinlik 5)

"Bisiklete Biniyorum” etkinliği ile öğrencilerden bisiklet kullanmaları istenerek basit makinelerden dişliler üzerinde durulur. (Ek 6, Etkinlik 6)

“İşten Kazanç Yok” etkinliği ile öğrencilerden çeşitli yükleri el arabası yardımıyla ve el arabası olmadan okul bahçesinin bir ucuna taşımaları istenerek basit makinelerle yapılan işin değişmeyeceği üzerinde durulur. (Ek 6, Etkinlik 7)

“Kendi Makinemi Tasarlyyorum” etkinliği ile öğrencilerden şimdiye kadar ki bilgilerine dayanarak işlerini kolaylaştıracak bir basit makine tasarlamaları istenir. Bu etkinlik uygulanan yöntemin en çok üst düzey düşünme gerektiren kısmıdır ve öğrenilen bilgiyle hayattaki ilişkili problemleri çözmeyi gerektirir. Bu yüzden bu etkinlik ayrıntılı bir şekilde aşağıda belirtilmiștir: (Ek 6, Etkinlik 8)

Öğretmen öğrencilerinden okul bahçesindeki limon ağaçlarından limonları toplamalarını ister.

Öğrenciler boylarının yettiği yerlerden limonları alırlarken uzanamadıkları yerlerdeki limonları toplayamamışlardır.

> Öğretmen öğrencilerinden ağaca çıkmadan yüksekteki limonları nasıl toplayacaklarını sorar.

> Öğrenciler bu çalışma için öğrendikleri bilgilere dayanarak uzun bir makas gibi çift taraflı kaldıraç tasarlayarak limonları toplayabileceklerini belirtirler. Bunun için okul bahçesinden tedarik ettikleri iki uzun tahta parçasının ortasına delik açtıktan sonra bu tahta parçalarını bir eğik düzlem örneği olan cıvata ile birleştirirler. Cıvatayı da bir çıkrık örneği olan tornavida ile sıkıştırırlar.

$>$ Öğrenciler bu basit makineyi tasarlarken her adımda kullandıkları araç ve gereçlerin hangi basit makine türlerine ait olduklarını da belirtirler. 
> Tasarladıkları basit makinenin saplarından tutarak makas gibi açarlar ve makinenin uç kısımlarıyla limonları tutarak ağaçtan kopartırlar.

> Bu etkinlik ile öğretmen öğrencilerin kendi başına tasarım yapabilecekleri bir problem durumu ortaya koymuştur. Öğrenciler basit makineler ünitesinde öğrendikleri bilgilerini günlük hayatla ilişkilendirip gerçek bir problemi çözmüşlerdir.

$>$ Köy Enstitülerinde de bugün probleme dayalı öğrenme dediğimiz, disiplinler arası ve gerçek yaşamdan problemlerin çözümünü gerektiren, öğrencilerin problem çözme ve yaratıcllk becerilerinin gelişiminin öne çıkarıllı̆̆1 uygulamalarla öğretim yapılmaktaydı. Bu anlamda öğrencilerin yaptığ1 bu çalışma enstitü örnekleriyle de benzeşmektedir. Yine özellikle öğrencilerin yaptıkları bu çalışma deney grubundaki öğrencilerin tupk1 Köy Enstitülerindeki öğrenciler gibi gerçek yaşamdan problemleri çözebilecek düzeye geldiklerini gösterebilir.

Öğrencilere bir iş yaptırarak, yaparak yaşayarak öğrenebilecekleri etkinliklerin hazırlanması hedef olduğundan uygulamaya ilk olarak hangi ünite ve hangi yaş grubu buna daha uygun sorusuyla başlanmıştır. Ünite ve sınıf belirlendikten sonra amaca en iyi şekilde hizmet edeceği inanılan etkinlikler hazırlanmıştır. Etkinliklerin hangi aralıklarla yapılacağı ve konunun hangi kısımlarında yapılacağına karar verilmiştir. Yapılacak işlerin yoğunluğundan haftada bir etkinlik yapılması uygun görülmüştür.

Öğrenci, yapacağı iş ve etkinlikleri onu sadece öğretmeninin ondan istediği bir iş olarak ya da eğlence öğesi olarak görmemeli, yaptığı işin hedeflenen kazanımlara ulaşabilmesinde etkili olduğunun da farkına varmalıdır. İş yaparken tüm öğrencilerin çalışması sağlanmalı, soru cevaplarla öğrencilerin dikkati hep üst düzeyde tutulmalıdır. Yapılacak işlerin alternatif çözüm yolları, hangi basit makineleri kullandıkları ya da bu iş için başka hangi basit makinenin kullanılabileceği gibi sorularla öğrencilere beyin firtınası yaptırarak hedef davranışlara daha kısa sürede ulaşılabilir.

Kontrol Grubunda Uygulanan Etkinlik Örnekleri:

Çiviyi çıkaralım (Ek 7)

$>$ Basit makineyi tanımlayalım (Ek 7)

$>$ Daha Kolay Nas1l Hareket Ettiririz? (Ek 7)

Bu etkinliklerin yapılmasında $5 \mathrm{E}$ yöntemi uygulanmıstır.

Girme: Ünitenin adı kazanımları öğrencilere sunulur. Öğrencilerin ilgisini çekecek bir etkinlikle derse devam edilir. Tahta takoza çakılmış çivinin tahtadan nasıl çıkarılacağı öğrencilere sorulur. Cevaplar dinlenir. Öğrencilere doğru cevaba dair bir dönüt verilir ve ardından diğer işlemlere geçilir. Bir açacak ile gazoz kapağ1 açma, fıstık kıracağı ile fistık kırma, makas ile kağıt kesme gibi etkinlikler öğretmen tarafından yapilır. Bütün bunların nasıl gerçekleştirildiği ile ilgili fikirler alınır. Motivasyon ve dikkat çekme sağlanır, ön bilgiler yoklanır.

Keşfetme: Bu aşamada öğrencilerin basit makine kavramını keşfetmelerini sağlayacak "basit makineyi tanımlayalım” etkinliği uygulanır. Bu basamakta basit makinelere örnekler verir ve sağladığı avantajları örneklerle açıllar kazanımı kazandırılmaya çalışılır.

Açılama: Öğrencilerden keşfetme aşamasındaki deneyimlerinden yola çıarak kaldıraçların çalısma prensiplerini açıklamaları istenir.

Derinleştirme: Bu basamakta bir önceki basamakta öğrencilerin edindikleri bilgileri kullanması sağlanır. Buna yönelik olarak "Daha Kolay Nasıl Hareket Ettiririz?” etkinliği uygulanır. Ardından öğrencilerden kaldıraçlara günlük hayattan örnekler vermeleri istenir. Öğrencilerin genellemelere gitmesi sağlanır. Bu noktada hala kavram yanılgısına sahip olanlar veya anlatılanları anlamamış olanlar varsa bunlar tespit edilecektir. Öğrencilerin birbiri ile etkileşim halinde olmaları sağlanacak cevaplar için birbirleri ile tartışmalarına firsat verilecektir. Bu süreçte öğrencinin aktif olması sağlanmaya çalışılacaktır.

Değerlendirme: Ders kitabı ünite değerlendirme soruları cevaplandırılır. 


\subsection{Verilerin Analizi}

Araştırmadaki katılımcılara uygulanan ölçeklerden elde edilen veriler kodlanarak bilgisayara yüklenmiştir. Elde edilen verilerin çözümlenmesinde SPSS 15,0 (Statistical Package for Social Sciences) istatistik program1 kullanılmıştır.

Araştırmada verilerin analizleri öncesinde, elde edilen verilerin yapılacak analizlerin varsayımlarını karşılayıp karşılamadığını test etmek için $\mathrm{N}<30$ olduğundan verilerin normallik dağılımları Shapiro-Wilk Testi ile değerlendirilmiştir. Katılımcıların ölçek puanlarının normal dağıllım gösterdiği ( $p>0,05)$ belirlenmiştir. Bu durumda puanlar arasındaki farklılığın anlamlı olup olmadığını belirlemek amacıyla parametrik testlerin kullanılması uygun görülmüştür.

Araştırmanın tanımlayıcı verileri sayı, ortalama, standart sapma, frekans (f) ve yüzde (\%) ile değerlendirilmiştir. Veri toplama aracı olarak hazırlanan ölçeklerden elde edilen veriler amaçlarda verilen durumlara uygun istatistiksel tekniklerle analiz edilmiştir. Buna göre çalışma kapsamında kullanılan ölçekler öğrencilere süreç başında ve süreç sonunda iki kere uygulanmıştır. Ölçeklerin ön-test son-test verilerinin deney-kontrol gruplarındaki farklarını incelemek için tek faktörlü varyans analizi testi kullanılmıştır. Deney ve kontrol grubu öğrencilerine son test olarak uygulanan başarı ve tutum puanları arasında bir ilişkinin var olup olmadığının değerlendirilmesi için Pearson korelasyon analizi kullanılmıştır. Tüm testlerde p değerinin 0.05 veya daha küçük olması anlamlı kabul edilmiştir.

\section{BULGULAR}

\subsection{Birinci Alt Probleme Ait Bulgular}

Köy Enstitüsü örneklerinin yansımalarıla fen öğretiminin yapıldı̆̆ı deney grubu öğrencileri ile mevcut öğretim programının önerdiği yöntemin uygulandığı kontrol grubu öğrencilerinin, başarı puanları arasında anlamlı bir fark var midir?

Ho: Deney ve kontrol grupları ile başarı testi puanları arasında anlamlı bir fark yoktur.

Tablo 2. Bașarı testi ile ilgili deney ve kontrol gruplarının aldıkları ön test-son test ortalama puan farkları ve standart sapma değerleri

\begin{tabular}{lrrr}
\hline Bağımlı Değişken: BAŞARI_SON_ON & & \\
\hline GRUPLAR & Ortalama & Standart Sapma & N \\
\hline DENEY & 34,78 & 17,99 & 23 \\
KONTROL & 23,09 & 19,07 & 21 \\
Toplam & 29,2 & 19,22 & 44 \\
\hline
\end{tabular}

Tablo 3. Başarı testi ile ilgili deney ve kontrol gruplarının karşılaştırıldığı varyans analizi sonuçları

\begin{tabular}{|c|c|c|c|c|c|}
\hline \multicolumn{6}{|c|}{ Değişkenler Arasındaki Testler } \\
\hline \multicolumn{6}{|c|}{ Bağımlı Değişken: BAŞARI_SON_ON } \\
\hline & II Tür Kareler Ortalaması & Serbestlik & Kareler & & \\
\hline Kaynak & & Derecesi & Ortalamas1 & $\mathrm{F}$ & $\mathrm{p}$ \\
\hline Düzeltilmiş Model & $1499,43 a$ & 1 & 1499,43 & 4,37 & 043 \\
\hline Kesişim & 36772,16 & 1 & 36772,16 & 107,26 &, 000 \\
\hline GRUPLAR & 1499,43 & 1 & 1499,43 & 4,37 &, 043 \\
\hline Hata & 14397,72 & 42 & 342,80 & & \\
\hline Toplam & 53425,00 & 44 & & & \\
\hline Düzeltilmiş Toplam & 15897,15 & 43 & & & \\
\hline
\end{tabular}

Tablo 3'e göre yaptığımız Tek Faktörlü Varyans Analizi $[\mathrm{F}(1-42)=4.37, \mathrm{p}<.05]$ olduğundan Ho hipotezi red edilir. Deney ve kontrol grupları ile başarı testi puanları arasında anlamlı bir fark vardır. Tablo 2'ye göre deney grubunun ortalaması 34,78, kontrol grubunun ortalaması ise 23,09 olarak hesaplanmıştır. Bu sonuçlara göre deney grubundaki öğrencilerin kontrol grubu öğrencilerine göre başarı testi puanlarında istatistiksel olarak anlamlı bir artış olmuştur. 


\section{2. İkinci Alt Probleme Ait Bulgular}

Deney grubu öğrencileri ile kontrol grubu öğrencilerinin, fen bilimlerine yönelik tutum puanları arasında anlamlı bir fark var midır?

Ho: Deney ve kontrol grupları ile fen bilimlerine yönelik tutum ölçeği puanları arasında anlamlı bir fark yoktur.

Tablo 4. Fen bilimlerine yönelik tutum ölçeği ile ilgili deney ve kontrol gruplarının aldıkları ön test- son test ortalama puan farkları ve standart sapma değerleri

\begin{tabular}{lrrr}
\hline Bağımlı Değişken: TUTUM_SON_ON & & \\
\hline GRUPLAR & Ortalama & Standart Sapma & N \\
\hline DENEY & 14,34 & 6,96 & 23 \\
KONTROL & 2,42 & 2,37 & 21 \\
Toplam & 8,65 & 7,98 & 44 \\
\hline
\end{tabular}

Tablo 5. Fen bilimlerine yönelik tutum ölçeği ile ilgili deney ve kontrol gruplarının karşılaştırıldığı varyans analizi sonuçları

\begin{tabular}{|c|c|c|c|c|c|}
\hline \multicolumn{6}{|c|}{$\begin{array}{l}\text { Değişkenler Arasındaki testler } \\
\text { Bağımlı Değişken: TUTUM_SON_ON }\end{array}$} \\
\hline Kaynak & Tür Kareler Ortalamas & $\begin{array}{l}\text { Serbestlik } \\
\text { Derecesi }\end{array}$ & $\begin{array}{r}\text { Kareler } \\
\text { Ortalamas1 }\end{array}$ & $\mathrm{F}$ & $\mathrm{p}$ \\
\hline Düzeltilmiş Model & $1559,52 \mathrm{a}$ & 1 & 1559,52 & 55,49 & 000 \\
\hline Kesişim & 3089,52 & 1 & 3089,52 & 109,93 & 000 \\
\hline GRUPLAR & 1559,52 & 1 & 1559,52 & 55,49 & 000 \\
\hline Hata & 1180,36 & 42 & 28,10 & & \\
\hline Toplam & 6039,00 & 44 & & & \\
\hline Düzeltilmiş Toplam & 2739,88 & 43 & & & \\
\hline
\end{tabular}

R Kare $=, 569($ Ayarlanmış R Kare $=, 559)$

Tablo 5’e göre yaptı̆̆ımız Tek Faktörlü Varyans Analizi $[\mathrm{F}(1-42)=55,49, \mathrm{p}<.05]$ olduğundan Ho hipotezi red edilir. Deney ve Kontrol grupları ile fen bilimlerine yönelik tutum ölçeği puanları arasında anlamlı bir fark vardır. Tablo 4'e göre Deney grubunun ortalaması 14,34, kontrol grubunun ortalaması ise 2,42 olarak hesaplanmıştır. Bu sonuçlara göre deney grubundaki öğrencilerin kontrol grubu öğrencilerine göre tutum ölçeği puanlarında istatistiksel olarak anlamlı bir artış olmuştur.

\section{3. Üçüncü Alt Probleme Ait Bulgular}

Deney ve kontrol grubu öğrencilerine son test olarak uygulanan başarı ve tutum puanları arasında anlamlı bir ilişki var mıdır?

Ho: Deney grubunda başarı ve tutum puanları arasında anlamlı bir ilişki yoktur.

Tablo 6. Deney grubu başarı ve tutum son test puanları arasındaki ilişkiyi gösteren korelasyon tablosu

\begin{tabular}{llcc}
\hline & & $\begin{array}{c}\text { BASARI_ } \\
\text { SON_TEST }\end{array}$ & $\begin{array}{c}\text { TUTUM_ } \\
\text { SON_TEST }\end{array}$ \\
\hline BAŞARI_SON_TEST & Pearson Correlation & 1 & $715^{* *}$ \\
& Sig. (2-tailled) & & 000 \\
& $\mathrm{~N}$ & 23 & 23 \\
\hline TUTUM_SON_TEST & Pearson Correlation &, $715^{* *}$ & 1 \\
& Sig. (2-tailled) & 000 & \\
& $\mathrm{~N}$ & 23 & 23 \\
\hline$* * \mathrm{p}<.01$ & & &
\end{tabular}

Tablo 6'ya göre başarı ve tutum son testlerinin ilişkisi Pearson Correlation katsayısı ile incelenmiştir. Bu test sonucu hesaplanan p değerleri Sig. (2-tailed) $<0,05$ olduğundan Ho hipotezi red edilir. Deney grubundaki öğrencilerin başarı ve tutum son test sonuçları istatistiksel olarak ilişkili çıkmışır. Başarı son testi ile tutum son testi arasında istatiksel bakımdan anlamlı pozitif yönde yüksek düzeyde bir ilişki olduğu gözlenmektedir $(\mathrm{r}=0.715, \mathrm{p}<.05)$.

Ho: Kontrol grubunda başarı ve tutum puanları arasında anlamlı bir ilişki yoktur. 
Tablo 7. Kontrol grubu başarı ve tutum son test puanları arasındaki ilişkiyi gösteren korelasyon tablosu

\begin{tabular}{llcc}
\hline & & $\begin{array}{c}\text { BAŞARI_ } \\
\text { SON_TEST }\end{array}$ & $\begin{array}{c}\text { TUTUM_ } \\
\text { SON_TEST }\end{array}$ \\
\hline BAŞARI_SON_TEST & Pearson Correlation & 1 &, $648^{*}$ \\
& Sig. (2-tailled) & &, 015 \\
& $\mathrm{~N}$ & 21 & 21 \\
\hline TUTUM_SON_TEST & Pearson Correlation &, $648^{*}$ & 1 \\
& Sig. (2-tailled) &, 015 & \\
& $\mathrm{~N}$ & 21 & 21 \\
\hline$* *$ p & &
\end{tabular}

Tablo 7'ye göre başarı ve tutum son testlerinin ilişkisi Pearson Correlation katsayısı ile incelenmiştir. Bu test sonucu hesaplanan p değerleri Sig. (2-tailed) $<0,05$ olduğundan Ho hipotezi red edilir. Kontrol grubundaki öğrencilerinde başarı ve tutum son test sonuçları istatistiksel olarak ilişkili çıkmıştır. Başarı son testi ile tutum son testi arasında istatiksel bakımdan anlamlı pozitif yönde yüksek düzeyde bir ilişki olduğu gözlenmektedir $(r=0.648, \mathrm{p}<.05)$.

\section{TARTIŞMA ve SONUÇ}

\subsection{Birinci Alt Probleme İlişkin Sonuçlar ve Tartışma}

Araştırmanın birinci alt problemi; “Köy Enstitüsü örneklerinin yansımalarıyla Fen öğretiminin yapıldı̆̆1 deney grubu öğrencileri ile mevcut öğretim programının önerdiği yöntemin uygulandığ1 kontrol grubu öğrencilerinin, başarı puanları arasında anlamlı bir fark var mıdır?” olarak düzenlenmiştir. Bu alt probleme yanıt bulmak amacıyla yapılan analizler sonucunda şu sonuçlara ulaşılmıştır:

Hem deney grubu öğrencilerinde, hem de kontrol grubu öğrencilerinde "Basit makineler” ünitesinde başarı puanlarında bir artış gözlenmiştir. Deney grubu öğrencileri ile kontrol grubu öğrencileri arasında akademik başarı puanları açısından anlamlı bir fark olduğu, farkın da deney grubu öğrencilerinin lehine olduğu ortaya çıkmıştır.

İlgili literatüre bakıldığında basit makineler ünitesinin farklı öğretim yöntemleriyle anlatıldığı ve akademik başarının incelendiği çalışmalar bulunmaktadır. Bu çalışmalara ve sonuçlarına bakıldığında; Ayvazoğlu (2016), yaptığı çalışma sonucunda Fen Bilimleri dersi 7. sınıf "Kuvvet ve Hareket" ünitesinde yer alan "Hayatımızı Kolaylaştıran Basit Makineler" konusunda eğlenceli eğitsel materyallerle yapılan fen aktivitelerinin öğrencilerin akademik başarılarını artırdığını belirtmiştir. Benzer şekilde Irkıçatal (2016), çalışma sonucunda mühendislik dizayn süreci doğrultusunda uygulanan Fen, Teknoloji, Mühendislik ve Matematik (FeTeMM) içerikli okul sonrası etkinliklerin yedinci sınıf öğrencilerinin basit makineler konusundaki başarılarını olumlu yönde etkilediği sonucuna ulaşmıştır. Çelik (2015), yaptığ1 çalışma sonucunda basit makineler konusunun film ve çizgi filmler ile öğretiminin öğrencilerin akademik başarısını artırdığını belirtmiştir. Burkaz (2012), yaptığı araştırma sonucunda Hayatımızı Kolaylaştıran Makineler konusunda, ön hazırlıklı üç boyutlu model sunumu ve 5E öğretim modeline uygun olarak yürütülen etkinliklerin öğrencilerin akademik başarılarını artırdığ1 sonucuna ulaşmıstır. Yılmaz (2005), ise basit makineler konusunun öğretiminde bilgisayar paket programları ile öğretim gören deney grubunun daha başarılı olduğu sonucuna ulaşmıştır. Telli (2002), basit makineler konusunda deneysel yöntem uygulayarak yaptığ1 çalışması sonucunda deneysel öğretim yönteminin öğrencilerin başarısına klasik yönteme göre anlamlı bir katkı sağladığını görmüştür.

Bu çalışmaların yanı sıra yaparak-yaşayarak öğrenmenin temelde olduğu, okul dışı öğrenme ortamlarında görülen eğitimin etkinliği ile ilgili de çalışmalar bulunmaktadır. Bu çalışmalara ve sonuçlarına bakıldığında; Pesen ve ark. (2000), yaptıkları çalışma sonucunda yaparak-yaşayarak öğrenme etkinlikleri ön plana çıkarılarak matematik dersi işlenen sınıfların başarı ortalamasının diğer sınıflardan daha yüksek olduğu sonucuna ulaşmışlardır. Bakioğlu (2017), okul dışı öğrenme ortamlarının (müzeler, hayvanat bahçesi, doğal ortamlar, botanik bahçeleri, okul bahçeleri vb.), öğrencilerin akademik başarılarını anlamlı bir şekilde artırdığı sonucuna ulaşmıştır. Yavuz (2012), Yanmaz (2017), Akça (2016) ve Akın (2012)’ de okul dişı öğrenme ortamlarının öğrencilerin akademik başarılarını artırdığı sonuçlarına ulaşmışlardır. Demir (2013), yaptığı doktora araştırması 
sonucunda farklılaştırılmış öğretim yöntemlerinden "İstasyon Yöntemi” nin öğrencilerin akademik başarılarını artırdığı sonucuna ulaşmıştır.

Yukarıdaki çalışmalara bakıldığında öğrencilerin ders içinde aktif olduğu, birçok duyu organına hitap eden, genelde uygulamaya yönelik olup öğrencilerin bizzat yaparak-yaşayarak öğrendiği ortamların öğrencilerin akademik başarılarını artırdığ1 söylenebilir. Çalışmada deney grubunun karşılaştırıldığı yöntem de öğrenci merkezli etkili bir yöntem olmasına rağmen deney grubundaki öğrencilerin başarılarının daha fazla olmasında bu öğrencilerin öğrendikleri konuları ve yaptıkları işleri günlük hayatla ilişkilendirebilmeleri, sadece sınıf içinde değil de sınıf dışında daha özgür çalışabildikleri ortamlarda öğretim görmeleri etkili olmuş olabilir.

\section{2. İkinci Alt Probleme İlişkin Sonuçlar ve Tartışma}

Araştırmanın ikinci alt problemi; "Deney grubu öğrencileri ile kontrol grubu öğrencilerinin, Fen Bilimlerine yönelik tutum puanları arasında anlamlı bir fark var mıdır?” olarak düzenlenmiştir. Bu alt probleme yanıt bulmak amacıyla yapılan analizler sonucunda şu sonuçlara ulaşılmıştır:

Hem deney grubu öğrencilerinde, hem de kontrol grubu öğrencilerinde tutum puanlarında bir artış gözlenmiştir. Deney grubu öğrencileri ile kontrol grubu öğrencileri arasında tutum puanları açısından anlamlı bir fark olduğu, farkın da deney grubu öğrencilerinin lehine olduğu ortaya çıkmıştır.

Ayvazoğlu (2016) da yaptığı çalışmada "Hayatımızı Kolaylaştıran Basit Makineler" konusunda eğlenceli eğitsel materyallerle yapılan fen aktivitelerinin öğrencilerin fene karşı tutum puanlarında artış meydana getirdiğini belirtmiştir. Benzer şekilde Çelik (2015), yaptı̆̆ı çalışmada basit makineler konusunun film ve çizgi filmler ile öğretiminin öğrencilerin fen bilgisi dersi tutum ölçeği son test puanlarını artırdığı sonucuna ulaşmıştır. Bilgin (2005) de, yaptı̆̆ı çalışma sonucunda yaparak yaşayarak yapılan fen etkinliklerinin ilköğretim sekizinci sınıf öğrencilerinin fen tutum ölçekleri ortalamalarını anlamlı şekilde artırdığını ortaya koymuştur. Yasak (2017), Fe'TeMM uygulamaları ile işlenen fen bilimleri konularında öğrencilerin derse olan tutumlarının anlamlı bir şekilde arttığı sonucunu ortaya koymuştur. Kılınç (2013), çalışması sonunda uyguladığı tutum ölçeği ile Coğrafya öğretiminde deney materyali kullanarak birçok soyut kavram ve konunun, yaparak ve yaşayarak öğrenme ile daha somut ve öğrencilerin ilgi ve merakını artıracak şekilde, eğlenceli olarak öğretilebileceğini ifade etmiştir. Bu sonuçların aksine Yılmaz (2005), "İlköğretimde basit makineler konusunun öğretiminde paket programların öğrenci başarısına etkisi" başlı̆̆ılla yaptığı çalışmada öğrencilerin fen bilgisi dersine yönelik tutumlarında anlamlı bir fark çıkmadığını belirtmiştir. Aynı şekilde Bakioğlu (2017), okul dışı öğrenme ortamlarının, öğrencilerin tutumlarında kontol gruplarıyla arasında anlamlı bir farkın olmadığını belirtmiştir.

Bu çalışmalara bakıldığında derslerin daha eğlenceli geçtiği, etkili öğrenme ortamlarının sağlandığ1, grup çalışmalarının yapılabildiği, öğrencilerin yaparak yaşayarak öğrendiği öğrenme ortamlarının öğrencilerin derse karşı olan tutumlarını artırdığı söylenebilir. Deney grubundaki öğrencilerin tutum puanlarının daha fazla çıkmasında ise derslerin bahçede işlenmesi, yapılan etkinliklerin öğrencilerin ilgisini daha çok çekmesi, yaptıkları işler sayesinde günlük hayattan gerçek bir problem durumunu (Ek6, Etkinlik 8) çözmeleri ve bu yüzden kendilerine daha çok güvenmeleri etkili olmuş olabilir. Bununla birlikte bir öğrencinin bir derse karşı olan tutumunun değişmesi zaman alan bir süreçtir. Kısa süreli öğrenme durumlarının öğrencilerin tutumlarının değişmemesinde etkili olduğu da ifade edilebilir.

\section{3. Üçüncü Alt Probleme İlişkin Sonuçlar ve Tartışma}

Araştırmanın üçüncü alt problemi; "Deney ve kontrol grubu öğrencilerine son test olarak uygulanan Başarı ve Tutum puanları arasında anlamlı bir ilişki var mıdır?” olarak düzenlenmiştir. Bu alt probleme yanıt bulmak amacıyla yapılan analizler sonucunda şu sonuçlara ulaşılmıştır:

Tablo 6 ve Tablo 7’ye bakıldı̆̆ında r değerinin deney grubunda daha yüksek çıktığ1 görülmüştür. Fakat, çıkan bu değerler hem deney grubunda, hem de kontrol grubunda başarı ile tutum puanları arasında anlamlı yüksek düzeyde bir ilişki olduğunu ortaya çıkarmıştır. Benzer şekilde Çağlar (2010), Akgün ve ark. (2007), Sünbül ve ark. (2003), Gürkan ve Gökçe (2000), Çakır ve ark. (2000), Simpson ve Oliver (1990), Fraser ve Butts (1982)'da yaptıkları çalışmalarının sonucunda Fen Bilgisi dersine yönelik başarı ve tutum arasında anlamlı 
bir ilişki olduğunu ifade etmişlerdir. Her iki grupta da yapılan etkinliklerin bizzat öğrenciler tarafindan yapılması, günlük hayattan örnekler içermesi öğrencilerin başarısını artırdığı ve buna paralel olarak da tutumlarını olumlu yönde etkilediği söylenebilir. Yine buradan hareketle herhangi bir dersten başarılı sonuçlar alınmak isteniyorsa etkili öğretim yöntemleriyle öğrencilere dersler sevdirilebilir ve bunun sonucunda öğrencilerin derse karşı olumsuz tutum geliştirmelerinin önüne geçilmesi hedeflenebilir.

Basit makineler ünitesi matematik bilgisi de içerdiğinden fen bilimleri dersinde zor ünitelerin başında gelir. Fakat gündelik yaşamla ilişkisi kurulabildiğinde öğrenciler bu konuyu çok iyi kavrayabileceklerdir. Çünkü basit makineler günlük hayatımızın hemen hemen her yerinde vardır. Çeşitli basit makineler yardımıyla günlük yaşamımızda birçok problemi rahatlıkla çözebilmekteyiz. Ünitenin uygulama olanaklarının çok olması, öğrencilerin bizzat bu basit makineleri kullanabilmeleri gibi durumlardan dolayı çalışmamızda bu üniteye yer verdik. İçinde bulunduğu dönem içerisinde başarıya ulaşmış, öğretimde özellikle bizzat yapma ve yaparak yaşayarak öğrenme etkinliklerine yer veren köy enstitüleri modelini de çalışmamıza örnek aldık. Enstitülerde bir konunun öğretilirken iş içinde öğretilmesi, bizim de çalışmamızda öğrencilere iş ya da etkinlikler yaptırarak öğretim yapmamız bu konuyu ve enstitüleri örnek almamızda etkili oldu. Aynı şekilde çalışma yapılan okulun da bir köy okulu olması ve bahçesinin iş ve etkinlik yapmaya uygun olması da bu temanın seçilmesinde etkili olmuştur. Köy enstitüleri örnek alınarak yapılan çalışmalar sonucunda basit makineler konusunda deney grubunda başarı ve tutum puanlarında kontrol grubuna göre anlamlı bir artış olmuştur. Bu puanların artışında, öğrencilerin ders sırasındaki işleri ve etkinlikleri severek yapmaları, yaparken eğlenmeleri, dersi sevmelerine ve başarılarının artmasına sebep olmuş olabilir. Bununla birlikte yapılan çalışmada kullanılan örneklem sayısı deneysel bir çalışma için çok sınırlıdır. Bu da çıkan sonuçların genellenebilirliği açısından yeterli olmayabilir.

\section{KAYNAKÇA}

Akça, Z. (2016). Mürị eğitimi veren kuruluşlarn fen eğitiminde kullamlmasmm ögrrencilerin akademik başarlarna ve bilimsel düsïnme becerilerine etkisi. Yüksek Lisans Tezi. Atatürk Üniversitesi, Erzurum.

Akgün, A., Aydın, M., \& Sünkür, M. Ö. (2007). İlköğretim bölümü öğrencilerinin fen derslerine yönelik tutumlarının çeşitli değişkenlere gore incelenmesi. Atatürk Üniversitesi Bayburt Ë̆itim Fakültesi Dergisi, 2(2), 1-14.

Akın,F. (2012). Okul içi ve okul dış ögrrenmelerin öğrenci başarssma etkisi.Yüksek Lisans Tezi. Mehmet AkifErsoy Üniversitesi, Burdur.

Armağan, B. (2015). Illkokul dördüncü smif fen öğretiminde okul dişı ögrenme ortamlar: Bir Eylem Arasțtrması. Yüksek Lisans Tezi. Dokuz Eylül Üniversitesi, İzmir.

Arslan, M. (2007). Eğitimde yapılandırmacı yaklaşımlar. Ankara Üniversitesi Eğitim Bilimleri Fakültesi Dergisi Cilt: 40, Say1: 1, 41-61

Ayvazoğlu, H. (2016). Fen ve teknoloji dersinde eğlenceli eğitsel materyallerin kullanmmmn öğrencilerin akademik bașarlarna ve fen tutumlar üzerine etkisi.YükseklisansTezi.Erzincan Üniversitesi, Erzincan.

Bakioğlu, B. (2017). 5. smnf vücudumu乏, bilmecesini çözelim ünitesinin okul dişı ögrenme ortamı destekliöğretiminin etkililĭ̈i. Doktora Tezi. Amasya Üniversitesi, Amasya.

Bilgin, İ. (2005). İşbirlikli öğrenmenin 8. Sınıf öğrencilerinin fen dersine karşı tutumlarına etkisinin incelenmesi. 14.09.2016 tarihinde http://ilkogretim-online.org.tr adresinden erişilmiştir.

Binbaşığlu, C. (1993). Çağdaş eğitim ve köy enstitüleri taribsel bir çerçeve. İzmir: Dikili Belediyesi: KültürYayınları.

Böyük, U., Saraçoğlu, S., \& Tanık, N. (2011). İlköğretim ikinci kademe öğrencilerinin bilimsel süreç beceri düzeylerinin çeşitli değişkenler açısındanincelenmesi. Türk Bilim araștırma V akfi Dergisi, 4(1),20-30.

Burkaz, S. (2012). Fen ve teknoloji ögretiminde ü̧̈ boyutlu modellerin yapılandırmac öğrenme ortamında kullanmm. Yüksek lisans Tezi. Recep Tayyip Erdoğan Üniversitesi, Rize.

Can, G. (2003). Psikolojik damısma ve rebberlik. Ankara: Pegema Yayıncilik, 56-58

Çă̆lar, A. (2010). Illköğretim ikinci kademe ögrencilerinin fen dersine yönelik tutumlar ve akademik benlik kavramlar. Yüksek lisans tezi. Çanakkale Onsekiz Mart Üniversitesi, Çanakkale. 
Çakır, Ö.S., Şahin, B. \& Yanpar, T. (2000). Türkiye'de farkh coğrafi bölgelerde bulunan okullardaki ögrencilerin fen bilgisi dersinde bilişsel ve duyussal açıdan karşılaş̧ırmalı olarak. incelenmesi, IV Fen Bilimleri Ë̆itimi Kongresi, Bildiriler Kitabı. Ankara:Milli EğitimBasımevi.

Çelik, S.Ö. (2015). 7.smnf basit makineler konusunun film ve çizggi filmler ile ögretimin tutuma ve akademik başarya etkisi. Yüksek Lisans Tezi. Erzincan Üniversitesi, Erzincan.

Çepni, S. (2007). Araștırma ve Proje Calısmalarna Giriș. Trabzon: Celepler Matbaacıllk.

Demir, S. (2013). Farkhlasttrilmış ögretim yöntemlerinin ögrencilerin akademik basar, ögrenme yaklaşımlar ve kahcollk puanlar üzerindeki etkisi. Doktora tezi. Yıldız Teknik Üniversitesi, İstanbul.

Demirtaş, A. (1993). Çağdaş eğitim ve këy enstitüleri. İzmir: Dikili Belediyesi Kültür Yayınları.

Fraser, B. J. \& Butts, W. L. (1982). Relationship between perceived levels of classroom individualization and science-related attitudes. Journal of Research in Science Teaching.

Gökçe, Y.(2010). Köy enstitüleri ve fen eğğtimi. Yüksek Lisans Tezi. Muğla Üniversitesi,Muğla.

Gürdal, A. (2001). Çağdaş ilköğretim anlayışında fen eğitimin sorunları ve çözüm önerileri paneli. Marmara Üniversitesi Atatürk Ë̆itim Fakültesi ve Istanbul ili Milli Ë̆itim Müdürlüğ̈̆ İstanbul.

Gürkan, T. \& Gökçe, E. (2000). İlkögrretim ögrrencilerinin fen bilgisi dersine yönelik tutumlar, IV. Fen Bilimleri Eğitimi Kongresi, Bildiriler Kitabı. Ankara: Milli Eğitim Basımevi.

Hofstein, A ve Lunetta, V.N. (2004). The laboratory in science education: foundations for the twenty-first century. Science Education, 88, 28-54.

Irkıçatal, Z. (2016). Fen, teknoloji, mühendislik. ve matematik (FeTeMM) içerikli okul sonrası etkinliklerin ögrencilerin basarlarna ve FeTeMM algzlar üzerine etkisi. Yüksek lisans Tezi. AkdenizÜniversitesi,Antalya.

Jones, M.G., Andre, T., Negishi, A., Tretter, T., Kubasko, D., Bokinsky, A., Taylor, R., \& Superfine, R. (2003). Hands-on Science: The impact of haptic experiences on attitudes and concepts. Paper presented at the National Association of Research in Science Teaching Annual Meeting. Philadephia,PA.

Kaplan, M. (2002). Aydmlanma devrimi ve köy enstitüleri. Ankara: T.C. Kültür Bakanlığ1 Yayınları.

Kaplan, M., Oran, H., Akgöl, H., Metin, M., ve Güvendi, M. (1993). Çağdas eğitim ve köy enstitüleri. İzmir: Dikili Belediyesi Kültür Yayınları.

Kaptan, F. (1999). Fen Bilgisi Ögretimi. Ankara: Anı Yayınc1lk, 1-138.

Karasar, N. (2013). Bilimsel araștrma yöntemi. Ankara: Nobel Yayınc1lik.

Karasel, N. \& Özçınar, Z. (2008). Fen ve teknoloji disiplinin eğitim teknolojisi bakımindan incelenmesi. Ankara: Pegem A Yayincilik.

Kilınç, Y. (2013). Deney ve uygulamalarla coğrafya öğretimi. Modern yöntem ve tekniklerle coğrafya öğretimi.Ankara: Pegem Yayınevi.

Maskan, A, K., \&Maskan, M, H. (2007). İlköğretim 4. sınıf fen ve teknoloji ders kitabının değerlendirme ölçütleri yönünden incelenmesi. D.Ü.Ziya Gökalp Ë̈itim Fakïltesi Dergisi. 9, 22- 32.

Milli Eğitim Bakanlığı (2018). Fen bilimleri dersi (3, 4, 5, 6, 7 ve 8. Sınıflar) öğretim programı, Ankara:Talim ve Terbiye Kurulu Başkanlığı, MEB Yayınları

Pesen, C., Odabaş, A., \& Bindak, R. (2000). İlköğretim okullarında kullanılan matematik öğretim yöntemleri üzerine. 12.01.2018 tarihinde http://eb.ted.org.tr/index.php/EB/article/view/5299/1460 adresinden erişilmiştir.

Sünbül, A. M., Afyon, A., Yağı, D., \& Aslan, O. (2003). İlkögretim 2.kademe fen bilgisi derslerindeki akademik basaryn yordamada ögrencilerin ögrenme strateji, stil ve tutumlarmmn etkisi. XII. Ulusal eğitim bilimleri kongresinde sunulan bildiri, Antalya.

Şen Gümüss, B. (2009). Bilimsel öykülerle fen ve teknoloji eğitiminin ögrrencilerin fen tutumlarna ve bilim insan imajlarna etkisi. Yüksek Lisans Tezi. Hacettepe Üniversitesi,Ankara.

Simpson, R. D., ve Oliver, J. S. (1990). A summary of majör influences on attitude toward and achievement in science among adolescent students. Science Education.

Telli, A. (2002). Basit makinelerle baそ̨ fen konularmm ögretilmesinde deneysel yöntemin ögrrenci bassarssma etkisinin araştmlması, Yüksek Lisans Tezi. GaziÜniversitesi, Ankara. 
Timur, S. (2006). İlköğretim 7. sinf fen bilgisi dersinde işbirlikli ögrrenme yönteminin ögrrenci basararsina etkisi ,Yüksek Lisans Tezi. Onsekiz Mart Üniversitesi, Çanakkale.

Türkoğlu,P.(2000). Tonguçve Enstitïleri. İstanbul:Türkiye İşBankası KültürYayınları.

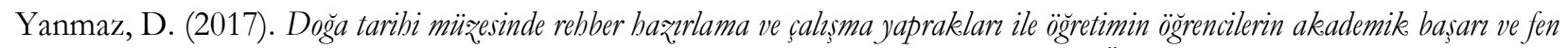
ögrenimine yönelike motivasyonlar üzerine etkisi, Yüksek Lisans Tezi. Muğla Sttk1 Koçman Üniversitesi, Muğla.

Yasak, M.T. (2017). Tasarım Temelli Fen Eğitiminde, Fen, Teknoloji, Mühendislik ve Matematik Uygulamaları: Basınç Konusu Örneği, Yüksek Lisans Tezi. Cumhuriyet Üniversitesi, Sivas.

Yavuz, M. (2012). Fen eğitiminde hayvanat bahçelerinin kullanımının akademik başarı ve kaygıya etkisi ve öğretmenögrenci görüşleri. Yüksek Lisans Tezi. Sakarya Üniversitesi,Sakarya.

Yılmaz, E. (2005). İlköğretimde basit makineler konusunun öğretiminde paket programlarının öğrenci başarısına etkisi. Yüksek Lisans Tezi. Selçuk Üniversitesi, Konya.

\section{Kaynak Gösterimi:}

Almalı, S., \& Akbaş, A. (2018). Ortaokul 8.sınıflar basit makineler ünitesine köy enstitüleri örneklerinin yansımaları. Dicle Üniversitesi Ziya Gökalp Eğitim Fakültesi Dergisi, 


\section{EKLER}

Ek - 6 Etkinlik 1 (Deney grubu örnek ders planı)

\section{6- 2017 EĞiTiM - ÖĞRETIM YILI 8. SINIF FEN BÍLIMLERI}

\section{DERS ve ETKINLIKK PLÂNI}

I.BÖLÜM

\begin{tabular}{|r|l|l|}
\hline Dersin Adı: & Fen Bilimleri & \\
\hline Sınıf: & 8. Sınıf \\
\hline Ünite No-Adı: & 2.Ünite:Basit Makineler \\
\hline Konu: & Basit Makineler \\
\hline Önerilen Ders & $40^{\prime}+40^{\prime}$ \\
\hline Saati: & \\
\hline
\end{tabular}

II.BÖLÜM

\begin{tabular}{|c|c|}
\hline $\begin{array}{r}\text { Öğrenci Kazanımları/Hedef ve } \\
\text { Davranışlar: }\end{array}$ & $\begin{array}{l}\text { 8.2.1.1. Basit makinelere örnekler verir ve sağladığı avantajları } \\
\text { örneklerle açıklar. } \\
\text { a. Basit makinelerden kaldıraç üzerinde durulur. }\end{array}$ \\
\hline Ünite Kavramları ve Sembolleri: & Kaldıraçlar \\
\hline $\begin{array}{r}\text { Uygulanacak Yöntem ve } \\
\text { Teknikler: }\end{array}$ & $\begin{array}{l}\text { Soru Cevap, Grup Çalışması, Yaparak - yaşayarak öğrenme (Köy } \\
\text { Enstitüleri) }\end{array}$ \\
\hline Kullanılacak Araç - Gereçler: & Çeşitli uzunluklarda tahta, Çeşitli yükler, El arabası, Kürek, Kazma \\
\hline Açıklamalar: & Basit makinelerden kaldıraç üzerinde durulur. \\
\hline Öğrenme ve Öğretme Etkinlikleri: & Etkinlik 1 \\
\hline
\end{tabular}

III.BÖLÜM

\begin{tabular}{|c|l|}
\hline Etkinlik Adı: & Çalışıyorum \\
\hline Etkinlik Amacı: & $\begin{array}{l}\text { Kullandıkları araç-gereçlerin birer basit makine olan kaldıraç } \\
\text { örnekleri olduklarını ve bu araçların iş yapma kolaylığı sağladıklarını } \\
\text { kavrayabilme }\end{array}$ \\
\hline Araç Gereçler: & Çeşitli uzunluklarda tahta, Çeşitli yükler, El arabası, Kürek, Kazma \\
\hline
\end{tabular}




\begin{tabular}{|c|c|}
\hline Etkinliğin Yapılışı: & $\begin{array}{l}\text { Öğretmenin "günlük yaşantımızı daha kolay hale getiren bir takım } \\
\text { makineler var mı?..” diye sorması ile ders başlar. Öğrenciler beyin } \\
\text { fırtınası yapıp fikirlerini ifade ettikten sonra, Öğretmenin “burada } \\
\text { bulunan çöp kovasının yerini değiştirmenizi ve buradaki malzemeler } \\
\text { yardımıyla tahterevalli yapmanızı istiyorum" demesi ile etkinlik } \\
\text { başlar. Öğrenciler iş bölümü yaparak bahçede bulunan malzemelerle } \\
\text { çöp kovasının yerini öğretmenin gösterdiği yer ile değişirler ve } \\
\text { tahtalarla tahterevalli örnekleri yaparlar. Bunu yaparken öğretmen } \\
\text { kaldıraçlarla ilgili kuvvet, kuvvet kolu, yük, yük kolu ve destek gibi } \\
\text { kavramların nereler olduğunu araç gereçler üzerinde sorar. } \\
\text { Öğrencilerinden bazen kuvvet kolunu bazen de yük kolunu } \\
\text { artırmalarını ve azaltmalarını ister. Örneğin küreği kullanırken kürek } \\
\text { sapının ortasından tuttuklarında ya da ucundan tuttuklarında, ya da } \\
\text { el arabasına atılan toprağı bazen tekere yakın bazen uzak } \\
\text { atmalarında, el arabasını tuttukları yerleri bazen yüke yakın bazen } \\
\text { yüke uzak tuttuklarında, tahterevallide desteğe yakın ya da uzak } \\
\text { durduklarında ne gibi değişiklikler hissettiklerini, hangi durumlarda } \\
\text { daha az kuvvet harcadıklarını sorar. }\end{array}$ \\
\hline Etkinliğin Sonucu: & $\begin{array}{l}\text { Öğrenciler kullandıkları kazma sayesinde toprağı kolaylıkla } \\
\text { kazabildiklerini, çıkan toprağı kürekle hızlı bir şekilde } \\
\text { kaldırabildiklerini ve el arabası sayesinde toprağın kolay ve hızlı bir } \\
\text { şekilde taşındığını belirttiler. Bu deneyimleri sonucunda kullandıkları } \\
\text { bu aletlerin hayatlarını kolaylaştıran birer basit makine örnekleri } \\
\text { olduklarını ifade ettiler. Kullandıkları kazma ve kürekte desteğin uçta } \\
\text { kuvvetin ortada olduğu, el arabasında desteğin uçta yükün ortada } \\
\text { olduğu tek taraflı kaldıraçlar olduklarını, tahterevallide ise desteğin } \\
\text { ortada olduğu çift tarafı kaldıraç tiplerine örnekler olduğunu } \\
\text { belirttiler. Yükün ortada olduğu kaldıraç tiplerinde el arabası } \\
\text { örneğindeki gibi az bir kuvvetle daha büyük yükleri taşıyarak kuvvet } \\
\text { kazancı sağladıklarını belirttiler. }\end{array}$ \\
\hline
\end{tabular}

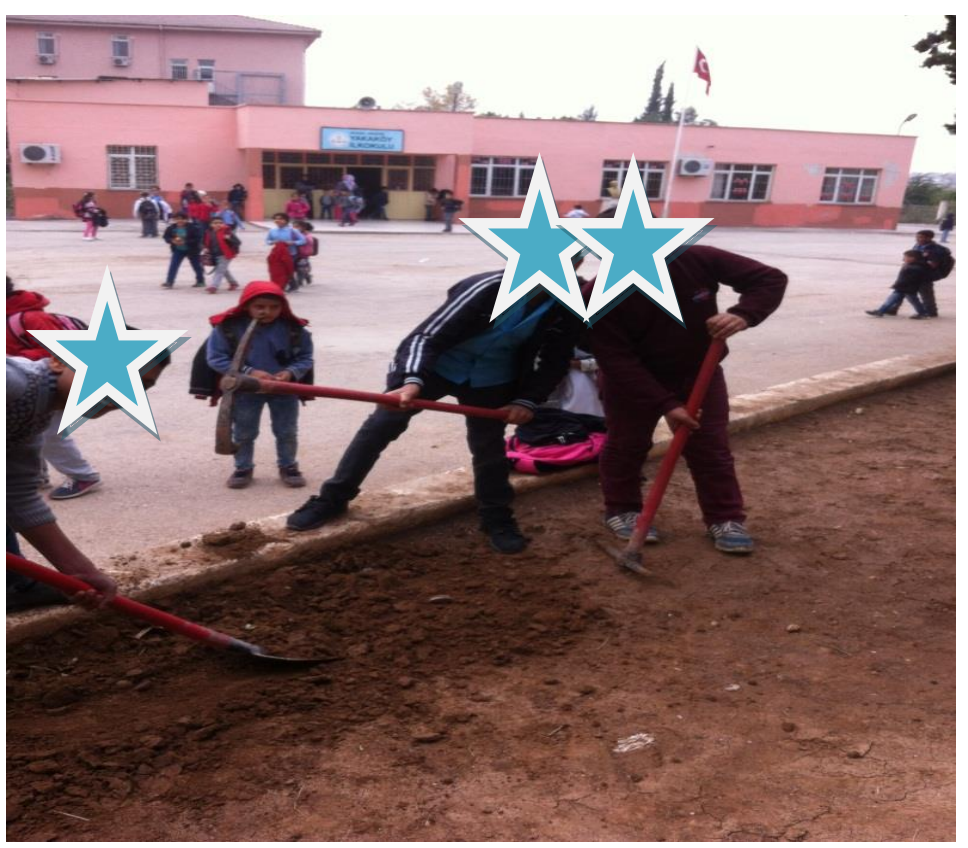

Şekil 1: Öğrenciler basit makineler kullanıp toprağı kazarken. 


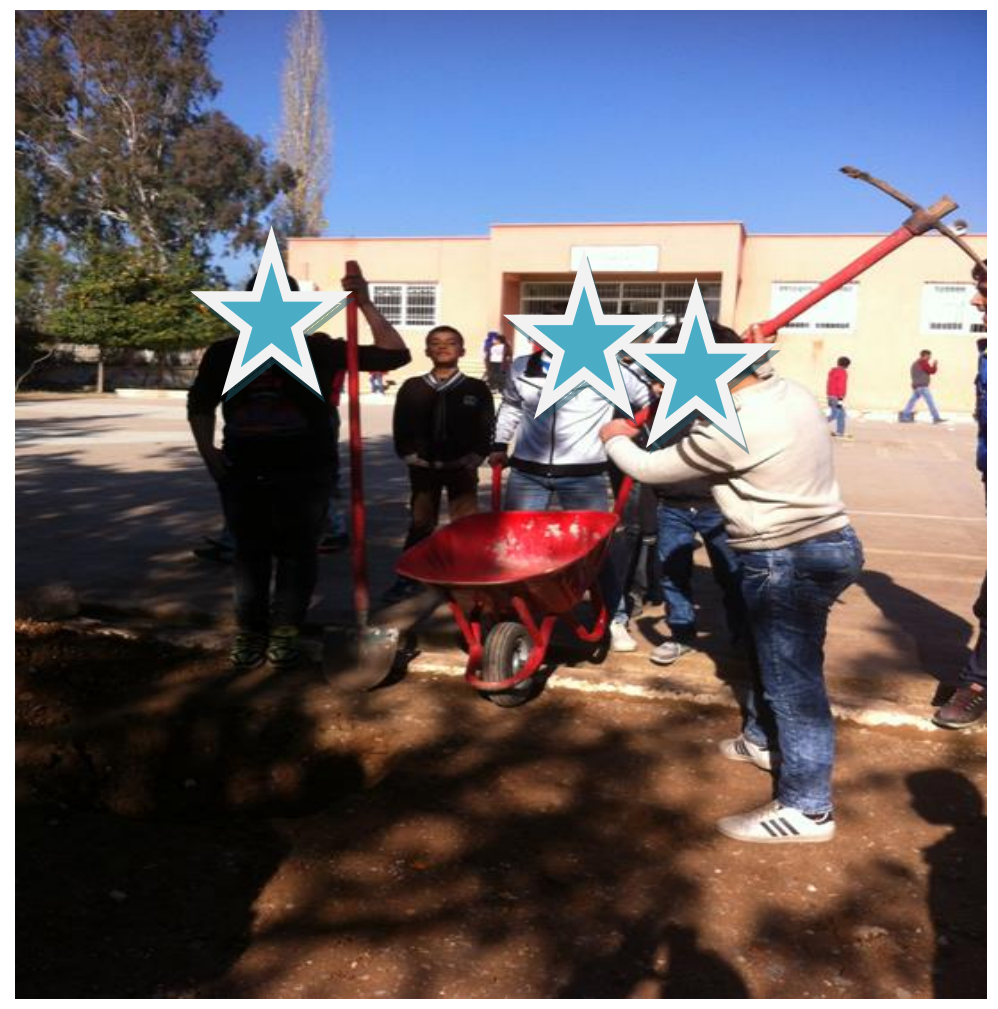

Şekil 2: Öğrenciler çöp kovasını yerleştirmek için çukur açarken.

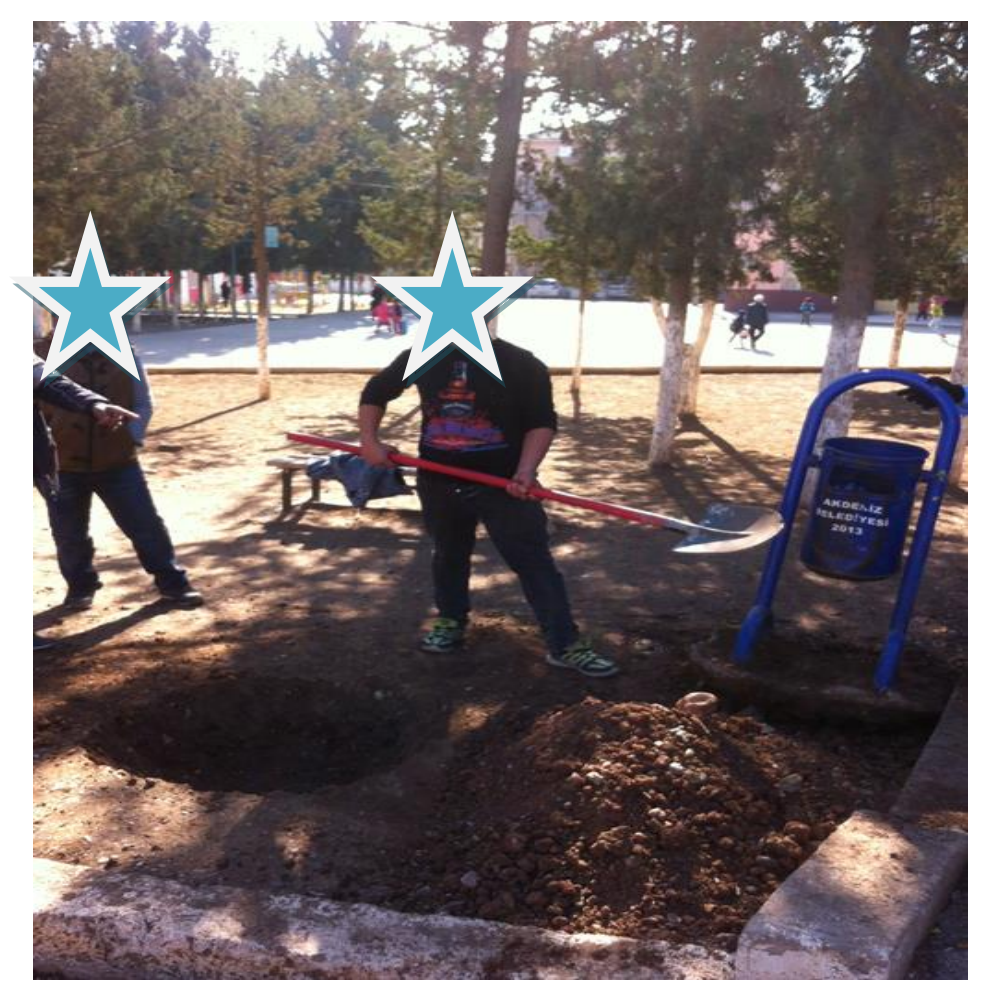

Şekil 3: Öğrenciler çöp kovasını yerleştirmek için hazırlanırken. 


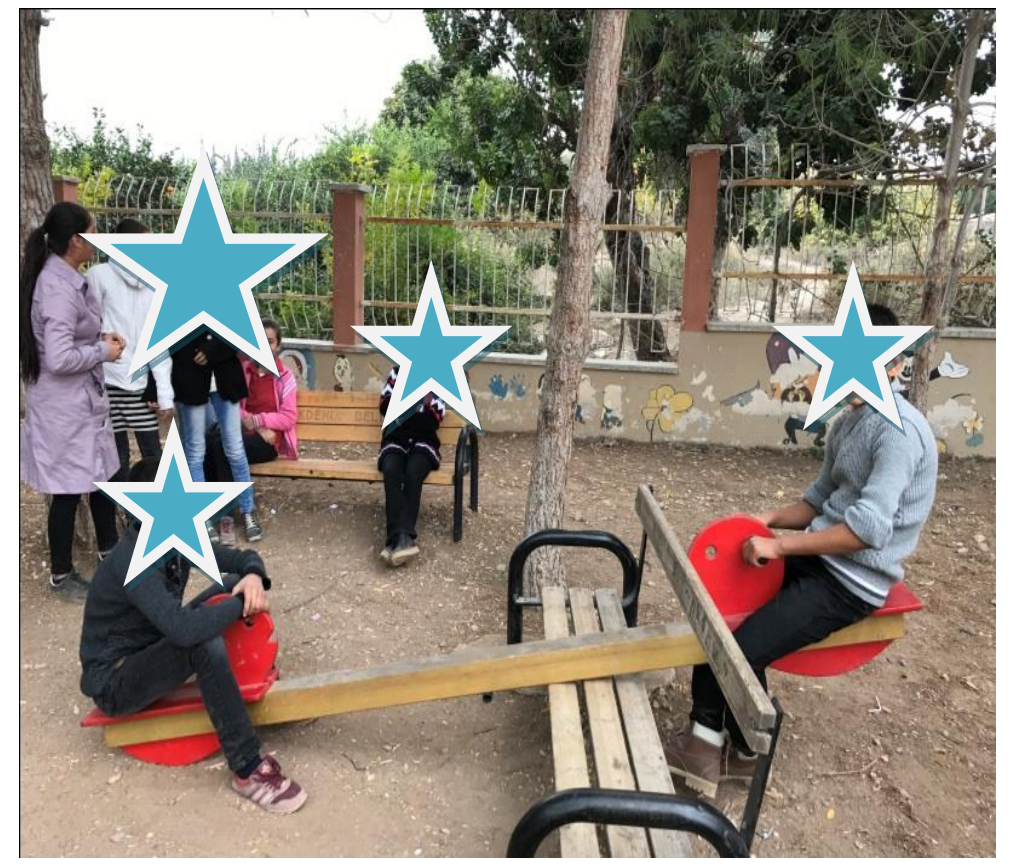

Şekil 4: Öğrencilerin oluşturdukları tahterevallide kuvvet kolunun fazla olduğu durum.

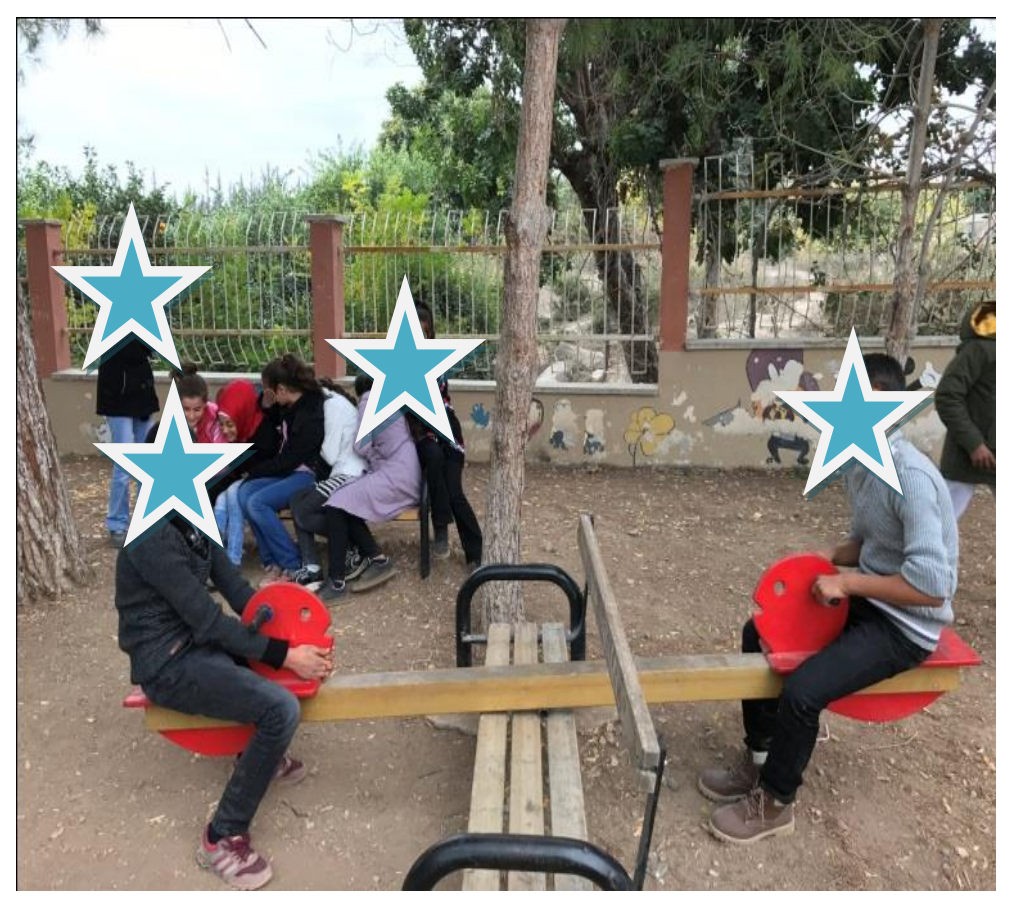

Şekil 5: Öğrencilerin oluşturdukları tahterevallide dengeyi sağladıkları durum. 


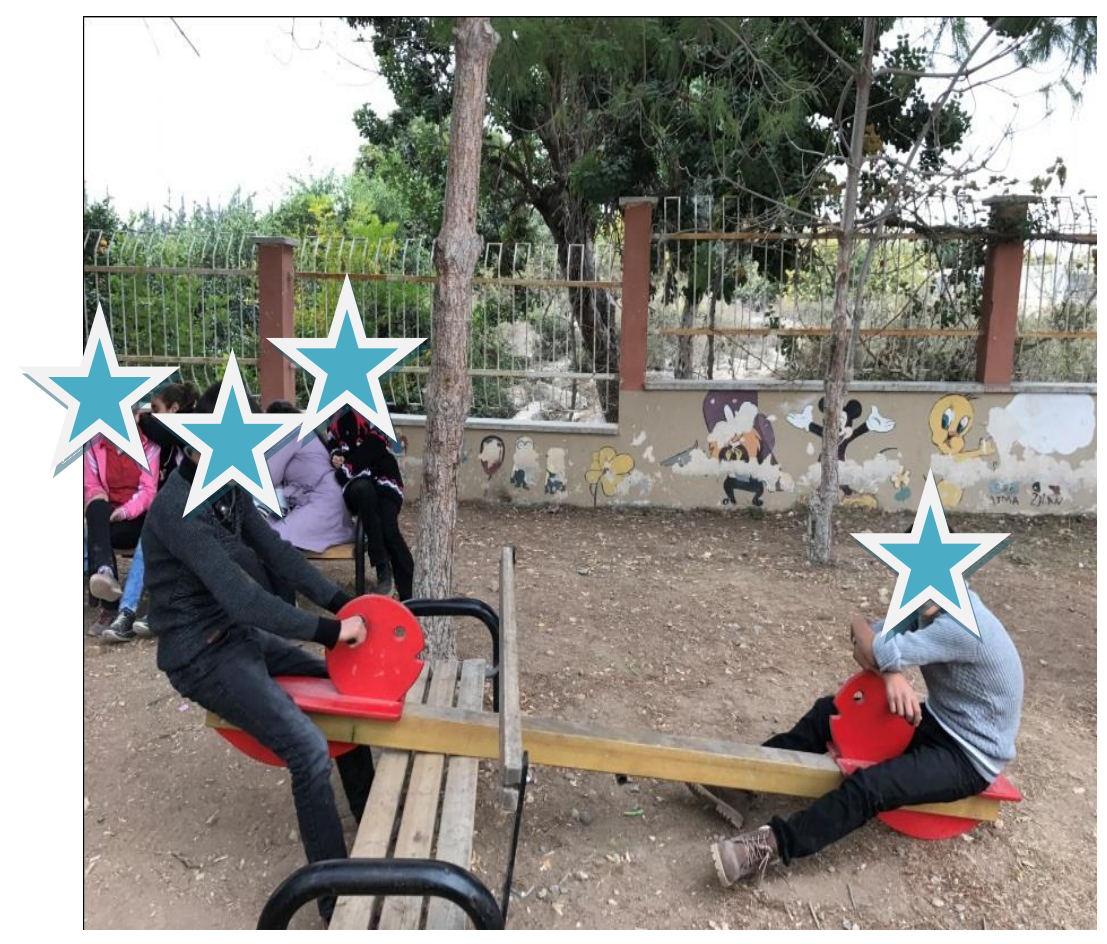

Şekil 6: Öğrencilerin oluşturdukları tahterevallide yük kolunun fazla olduğu durum. 


\section{Ek - 8 Köy Enstitüleri Çalışmalarına Örnek}

DUYARSAM UNUTURUM, GÖRÜRSEM HATIRLARIM, YAPARSAM ÖĞRENİRIM....Konfüçyus

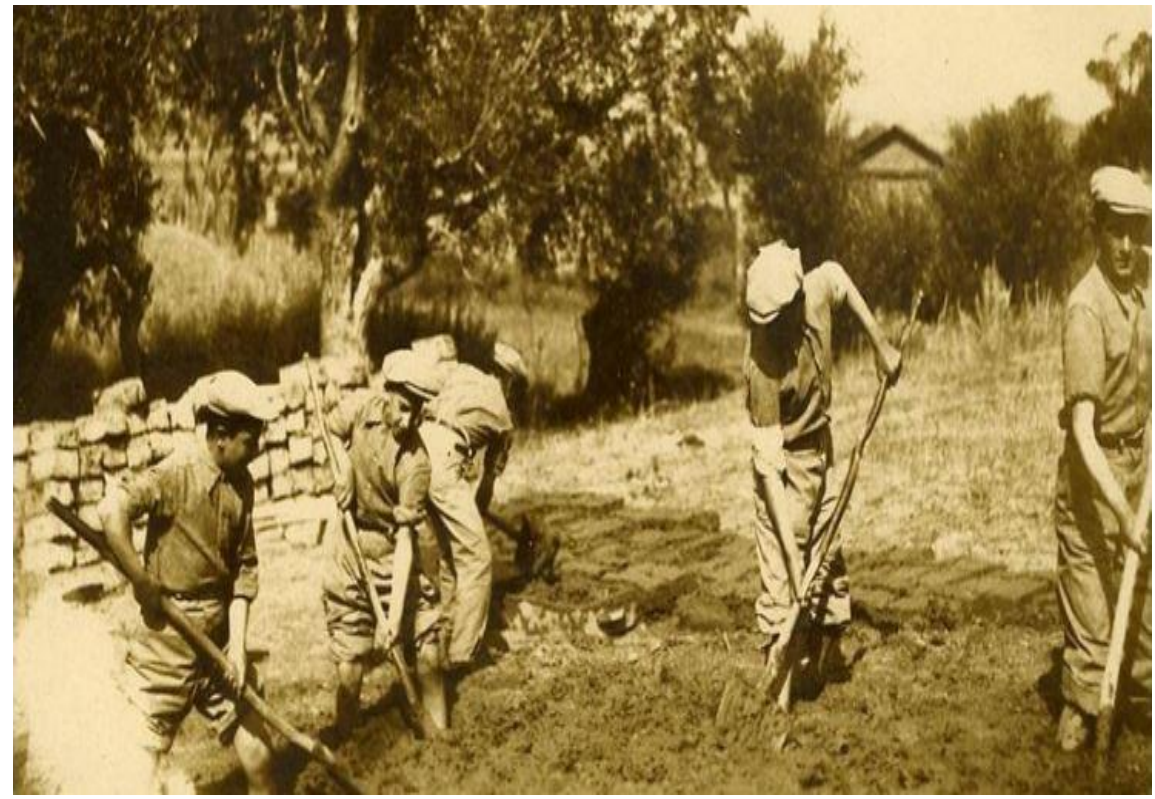

Öğrenciler bahçede çalışırken

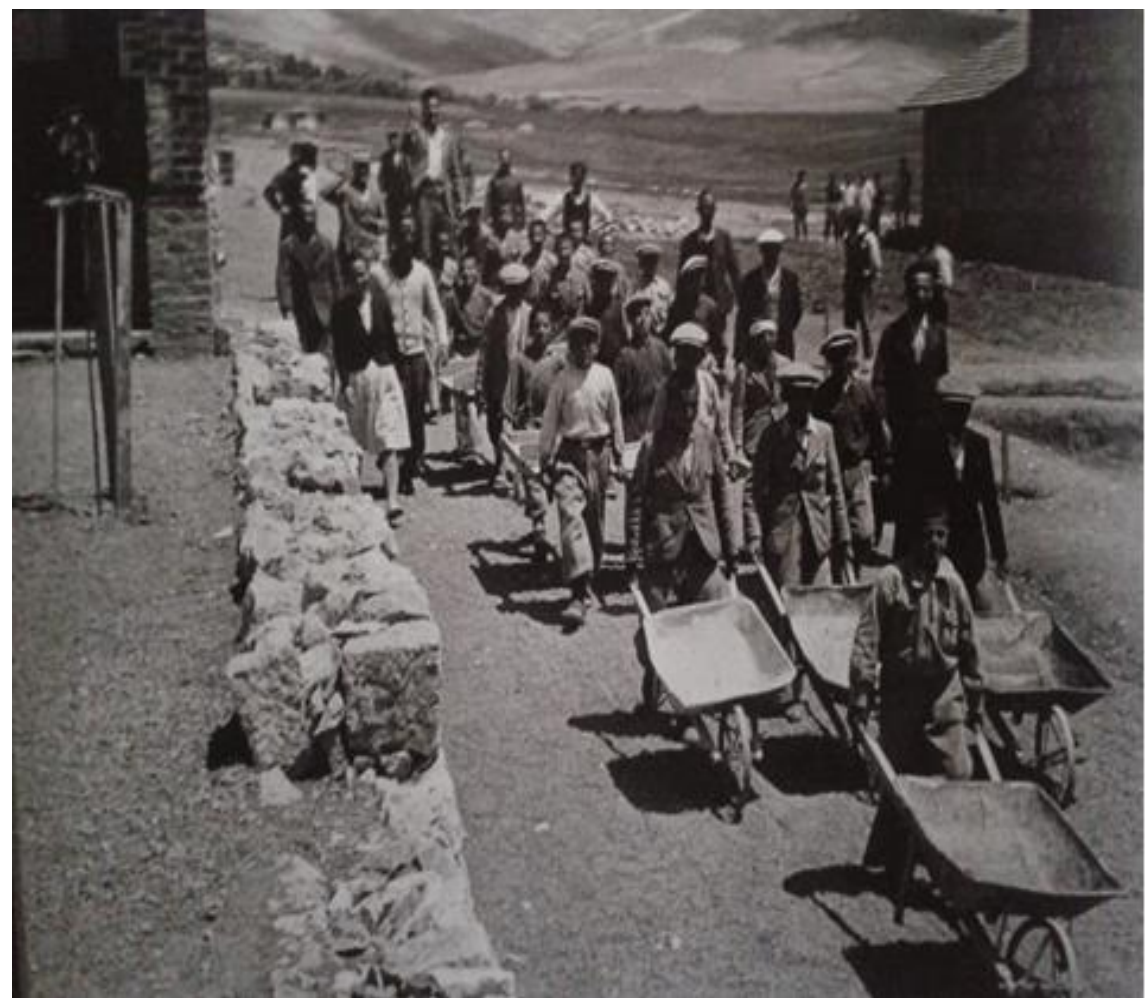

Öğrenciler el arabası yardımıyla çalışmaya gidiyor 